\title{
Species richness and composition of snake assemblages in poorly accessible areas in the Brazilian Amazonia
}

\author{
Luciana Frazã $0^{1,2 *}$, Maria Ermelinda Oliveira ${ }^{3}$, Marcelo Menin ${ }^{4,5}$, Juliana Campos $^{2}$, Alexandre Almeida ${ }^{2,5}$, \\ Igor L. Kaefer ${ }^{4,5}$ \& Tomas Hrbek ${ }^{2,5}$ (i) \\ 'Programa de Pós-Graduação em Biodiversidade e Biotecnologia da Amazônia Legal - BIONORTE, \\ Av. Carvalho Leal, 177, 69065-001, Manaus, AM, Brasil \\ ${ }^{2}$ Universidade Federal do Amazonas, Departamento de Genética, Instituto de Ciências Biológicas, Laboratório de \\ Evolução e Genética Animal, Av. General Rodrigo Octávio Jordão Ramos, 6200, 69077-000, Manaus, AM, Brasil \\ ${ }^{3}$ Universidade Federal do Amazonas, Instituto de Ciências Biológicas, Departamento de Parasitologia, Av. \\ General Rodrigo Octávio Jordão Ramos, 6200, 69077-000, Manaus, AM, Brasil \\ ${ }^{4}$ Universidade Federal do Amazonas, Departamento de Biologia, Instituto de Ciências Biológicas, Av. General \\ Rodrigo Otávio Jordão Ramos, 6200, 69077-000, Manaus, AM, Brasil \\ ${ }^{5}$ Universidade Federal do Amazonas, Instituto de Ciências Biológicas, Programa de Pós-Graduação em \\ Zoologia, Av. General Rodrigo Otávio Jordão Ramos, 6200, 69077-000, Manaus, AM, Brasil \\ *Corresponding author: Luciana Frazão,e-mail: luca.frazao@gmail.com
}

FRAZÃO, L., OLIVEIRA, M.E., MENIN, M., CAMPOS, J., ALMEIDA, A., KAEFER, I.L., HRBEK, T. Species richness and composition of snake assemblages in poorly accessible areas in the Brazilian Amazonia. Biota Neotropica. 20(1): e20180661. http://dx.doi.org/10.1590/1676-0611-BN-2018-0661

Abstract: Snakes are a diverse group of terrestrial vertebrates of the order Squamata. Despite that, in the Amazonian biome, information about distribution and identification of snakes is limited when compared to other groups. Additionally, in Amazonia there is a sampling bias towards areas geographically close to urban centers and more densely populated areas. This in turn leads to false distribution gaps in poorly accessible areas of Amazonia. In this article we report the composition of snake assemblages in six areas of the Brazilian Amazonia, based on field sampling conducted over four years using standardized methods. We sampled 70 species from eight families: Typhlopidae ( $\mathrm{n}=1)$, Leptotyphlopidae $(\mathrm{n}=1)$, Anillidae $(\mathrm{n}=1)$, Boidae $(\mathrm{n}=5)$, Colubridae $(\mathrm{n}=15)$, Dipsadidae $(\mathrm{n}=35)$, Elapidae $(n=7)$, and Viperidae $(n=5)$. The largest number of species was recorded in the Trombetas River area and the lowest in the Jatapu River area. The total beta diversity was 0.40 and the snake assemblages were structured mainly by replacement $(72.5 \%)$. The time-limited search was the method that recorded the greatest number of individuals in the studied areas $(44.1 \%)$ and also the greatest number of species $(n=40)$. However, some species were recorded only by other methods such as interception by pitfall traps with directional fences. Despite the large number of species sampled in the study, no particular area comprised more than $40 \%$ of species registered in all the areas, indicating that snakes are poorly detected even with large sampling effort across multiple areas of a species distribution.

Keywords: Amazon Basin, Brazil, Ophidia, sampling methods, Squamata.

\section{Riqueza de espécies e composição de assembleias de serpentes em áreas pouco acessíveis na Amazônia brasileira}

Resumo: Serpentes compõem um diverso grupo de animais vertebrados terrestres pertencentes à ordem Squamata. Apesar de serem um dos grupos mais diversos do mundo, na Amazônia, as informações acerca da taxonomia e distribuição de serpentes são limitadas quando comparadas com as disponíveis para outros grupos de vertebrados. Além disso, na Amazônia existe um viés de amostragem em áreas geograficamente próximas aos centros urbanos e locais densamente povoados. Isso por sua vez leva a falsas diferenças de distribuição em áreas pouco amostradas. Neste artigo nós apresentamos a composição de assembleias de serpentes em seis áreas na Amazônia brasileira, baseada em amostragens de campo padronizadas e realizadas durante quatro anos. Foram amostradas 70 espécies de oito famílias: Typhlopidae $(n=1)$, Leptotyphlopidae $(n=1)$, Anillidae $(n=1)$, Boidae $(n=5)$, Colubridae $(n=15)$, Dipsadidae $(n=35)$, Elapidae $(n=7)$ e Viperidae $(n=5)$. A maior riqueza foi registrada no Rio Trombetas e a menor no Rio Jatapu. A beta diversidade total foi de 0.40 e a substituição foi a principal força que estruturou as 
comunidades (72.5\%). A Procura Visual Limitada por Tempo foi o método que registrou a maior abundância de serpentes nas áreas amostradas $(44.1 \%)$ e também a maior riqueza $(n=40)$. Entretanto, algumas espécies foram registradas somente por outros métodos como armadilhas de interceptação e queda. Apesar do grande número de espécies registradas, nenhuma das áreas compreendeu mais de $40 \%$ das espécies amostradas em todas as áreas, indicando que as serpentes são pouco detectadas mesmo com grande esforço amostral em diferentes áreas da distribuição das espécies.

Palavras-chave: Bacia Amazônica, Brasil, métodos de amostragem, Ophidia, Squamata.

\section{Introduction}

Snakes are a diverse group of terrestrial vertebrates of the order Squamata with approximately 3500 known species. They inhabit temperate to tropical environments, and are found in terrestrial and aquatic habitats (Wallach et al. 2014, Uetz \& Hošek 2016). The Neotropical region comprises one of the world's richest herpetofaunas (Böhm et al. 2013, Meiri \& Chapple 2016) with Brazilian Amazonia comprising 189 snake species (Prudente 2017). In spite of this, the knowledge of snakes is poor when compared to other herpetofaunal groups and distribution data for snake species remain incomplete (Guedes et al. 2018). This is mainly due to the cryptic habits of snakes which makes them difficult to encounter (Kéry 2002, Steen 2010).

Detection of snakes is even more difficult in densely vegetated tropical forests (Fraga et al. 2014). Additionally, the large number of rare, fossorial and semi-fossorial species, which are usually ignored or sub-sampled, is an aggravating factor for the reliable inference of patterns of distribution and abundance (Rocha et al. 2005, Couto et al. 2007). This scenario makes it difficult to study taxonomy and systematics, infer biogeographic patterns and direct conservation efforts. Although some studies of Amazonian herpetofauna have been conducted in places far from urban centers (e.g. Frota et al. 2005, Prudente \& Santos-Costa 2005, Bernarde et al. 2006, 2011, 2013, Turci et al. 2008, França \& Venancio 2010, Ferrão et al. 2012, Pantoja \& Fraga 2012, Santos-Costa 2015, Vaz-Silva et al. 2015, Rodrigues et al. 2016, França et al. 2017, Fonseca et al. 2019), for example there is a sampling bias in favor of densely populated areas as shown for plants (Nelson et al. 1990).

For snakes, occurrence points are usually close to large urban centers (Guedes et al. 2018), such as Manaus (Martins \& Oliveira 1998, Fraga et al. 2013) and Belém (Ávila-Pires 1995, Silva et al. 2011, Prudente et al. 2013, 2018). In addition, comparisons between areas become difficult due to the different methods and sampling efforts employed in each study (Magnusson et al. 2005, Bernarde et al. 2012), which is also an issue for snakes (Bernarde et al. 2011, Guedes et al. 2018). Bernarde et al. (2013) observed that even though snakes have large geographic distributions in the Amazonian biome, only a small proportion of the total expected number of species occur - or are detected - at each location.

Indications of the lack of knowledge of assemblage composition and distribution of Amazonian snakes are the frequent descriptions of new species (e.g. Hoogmoed \& Prudente 2003, Myers \& McDowell 2014, Feitosa et al. 2015, Passos et al. 2019, Bernarde et al. 2018) and new occurrence records (e.g. Bernarde \& Moura-Leite 1999, Franco \& Ferreira 2003, Luiz et al. 2017, Fraga et al. 2017). Thus, faunal surveys are important tools to generate basic knowledge on regional diversity and its spatial distribution in Amazonia (Vaz-Silva 2009, França \&
Venâncio 2010, Miranda et al. 2014), being essential for decisionmaking and formulation of conservation policies.

The present study aims to increase the knowledge of distribution and beta diversity of snake assemblages in six unexplored areas of Amazonia. We provide information on the structure of snake assemblages such as composition, richness and relative abundance of species. We also compared the efficacy of the different sampling methods used in this study.

\section{Materials and Methods}

\section{Study area}

Sampling was carried out in six areas of Amazonia, on opposite margins of major Amazonian rivers (Figure 1). These areas are characterized as upland terra firme (non-flooded) forests and four areas (Jatapu River, Negro River, Purus River and Japurá River) are located in the western and central Amazonia, and the other two areas (Tapajós River and Trombetas River) are located in eastern Amazonia. These areas are classificated as "Af" according to Köppen's climate, with mean annual temperature greater than $26^{\circ} \mathrm{C}$ and the annual mean precipitation ranging from $2200 \mathrm{~mm}$ to $2700 \mathrm{~mm}$ (Alvares et al. 2013) (Table 1). These areas were chosen because they are still poorly studied in terms of Amazonian biodiversity, and generally are thought to belong to distinct areas of endemism (Cracraft 1985, Ribas et al. 2012).

\section{Sampling}

Sampling was carried out between September 2011 and September 2014 , always in the end of the dry season. In each sampling area two modules were established, one on each river margin. Each module was approximately $1 \mathrm{~km}$ from the river bank and was composed of three parallel 3000 meter linear transects separated by $1000 \mathrm{~m}$. Access to the trail system was via a 500 to $1500 \mathrm{~m}$ trail. Human settlements in the region were situated at least $10 \mathrm{~km}$ from the trail system, and consisted of few houses. The snakes were sampled in each module using the Time Constrained Search (TCS), pitfall traps with drift fences (PIT), Opportunistic Encounters (OE) and Occasional Encounters by Third Parties (OET) (Martins \& Oliveira 1998, Cechin \& Martins 2000, Sawaya et al. 2008).

The Time Constrained Search method consists of walking very slowly along forest trails searching for snakes; the search effort is extended to all visually accessible microhabitats (Martins \& Oliveira 1998). Each transect was sampled 10 times by this method between 18:30 and 22:00 by two observers, totaling an effort of 420 hours of searching in each area. 
Amazonian snake communities

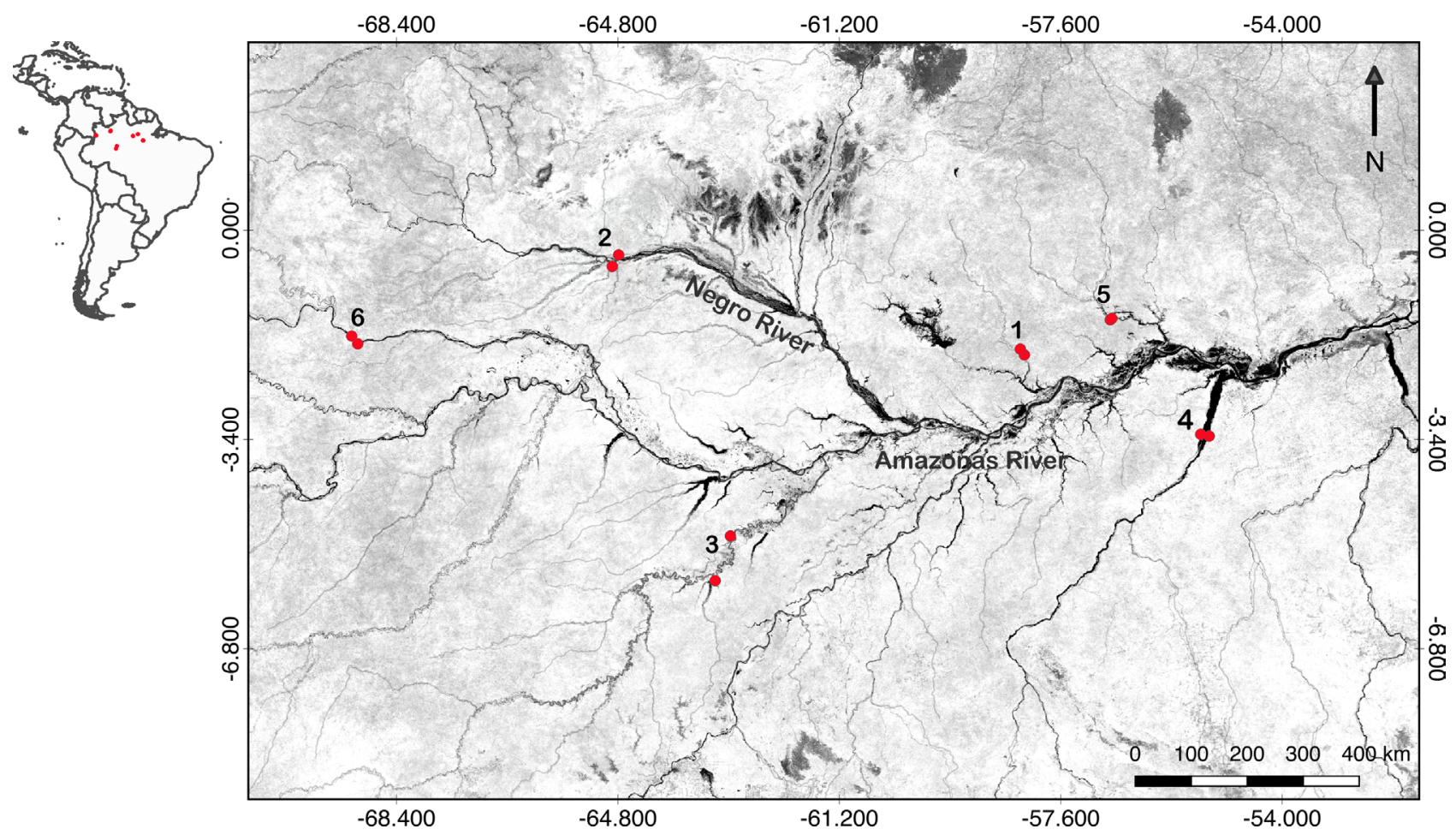

Figure 1. Location of study areas (pairs of red dots) in the Brazilian Amazonia based on the distribution of the main tributaries of the Amazon River, Brazil: 1) Jatapu River; 2) Negro River; 3) Purus River; 4) Tapajós River; 5) Trombetas River, and 6) Japurá River.

Table 1. Geographical location and environmental characteristics of each area sampled in the Brazilian Amazonia.

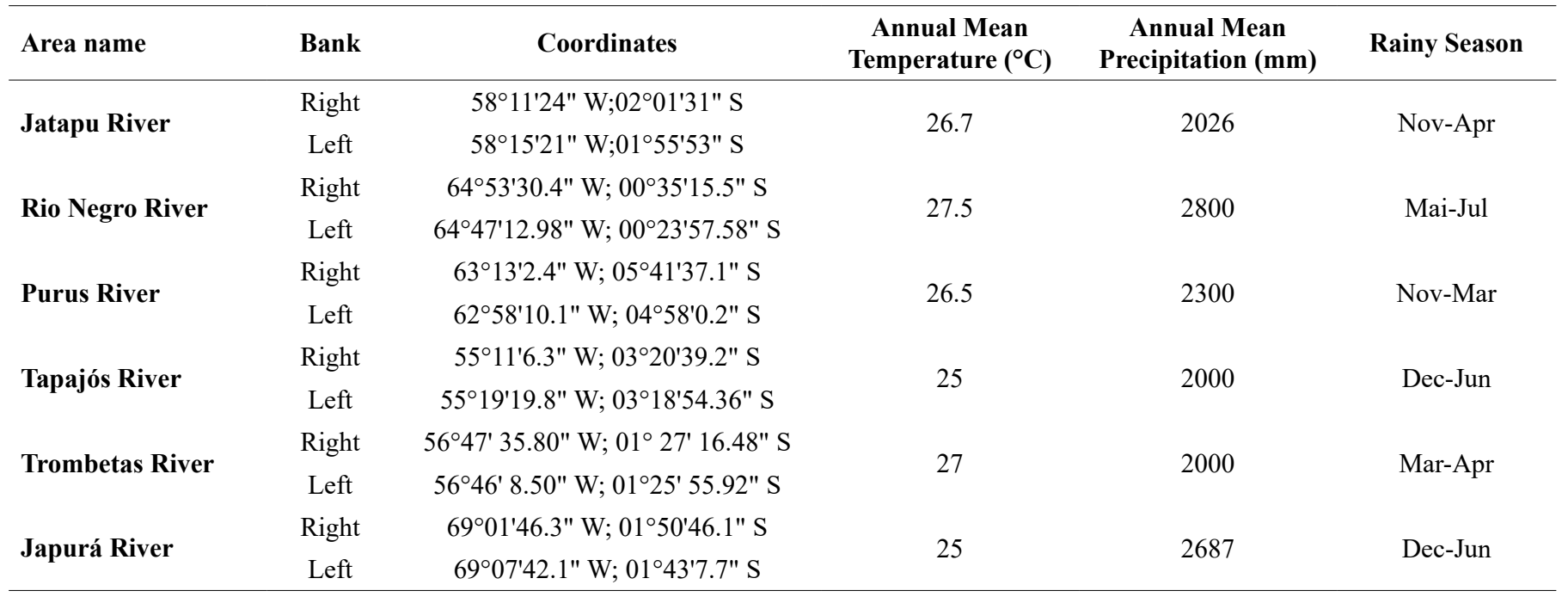

The pitfall traps (PIT) remained open for 20 days. Four trapping stations $500 \mathrm{~m}$ apart were set along each trail. Each array contained four bins (100 L; 51-cm mouth diameter $\times 69 \mathrm{~cm}$ deep) in a Y-formation (e.g. Cechin \& Martins 2000). The bins were separated by $10 \mathrm{~m}$ and linked by a polyethylene fence guide $(10 \mathrm{~m}$ long $\times 1 \mathrm{~m}$ high, with the bottom $10 \mathrm{~cm}$ of the fence buried in the ground). Specimens were recovered from the buckets daily. Thus, a total of 24 pitfall trap stations were checked each day to yield a total effort of 480 pitfall-days in each area.

The Occasional Encounters by Third Parties method of other researchers (in our case researchers sampling other taxonomic groups) collecting animals of interest (Cunha \& Nascimento 1978, Marques 1998) and Opportunistic Encounter occurs when the specimens are occasionally found during other activities performed by the researchers other than sampling, such as during the survey of the area to be sampled (Martins \& Oliveira 1998, Bernarde \& Abe 2006, Sawaya et al. 2008).

After collection, the specimens were euthanized, fixed in $10 \%$ formaldehyde, and subsequently deposited in the Coleção Zoológica Prof. Paulo Bührnheim (CZPB-RP) of the Universidade Federal do Amazonas and in the Coleção de Anfíbios e Répteis (INPA-H) of the Instituto Nacional de Pesquisas da Amazônia (INPA), both in Manaus, Brazil 
(Appendix I). The collections in the sampling areas were authorized by the Instituto Chico Mendes de Conservação da Biodiversidade (ICMBio/ Brazil) through licenses 41180-2, 35424 and 40186.

\section{Species identification and taxonomic considerations}

Specimens were identified to the level of species by taxonomists specialized in Neotropical snakes with any uncertainties resolved by conferring specialized literature (e.g. Cunha \& Nascimento 1993, Martins \& Oliveira 1998, Fraga et al. 2013, Bernarde et al. 2017). The names adopted in the present study follow Zaher et al. (2009), Carrasco et al. (2012), Grazziotin et al. (2012), and Costa \& Bérnils (2018), where Colubridae and Dipsadidae are classified as distinct families within the superfamily Colubroidea. Even after a careful morphological verification by specialists, following recent taxonomic keys, we could not assign multiple specimens of the genera Apostolepis, Drymoluber and Taeniophallus to species level. Therefore, we used the epithets Apostolepis aff. nigrolineata, Drymoluber aff. dichrous, and Taeniophallus aff. occipitalis. Although these epithets do not necessarily imply the existence of new species, they are a recognition of greater-than-expected morphological diversity and likely lineage diversity within these genera.

\section{Data analysis}

The diversity of the sampled assemblages was evaluated through species richness which consists of the total number of species identified in an area of interest (Peet 1974, Wilsey et al. 2005). To compare diversity among snake assemblages in the sampled areas we used beta diversity (Whittaker 1960) and diversity profiles, based on the Hill's series (Peet 1974).

Beta $(\mathrm{P})$ diversity is used to describe the spatial dynamics of the snake communities sampled through the processes of replacement and nestedness (Legendre 2014). The replacement process measures the rate at which one set of species replaces the other between areas (Lastrom et al. 2015). Nestedness measures the difference of richness between areas, being defined by the degree of dissimilarity between them, but only in the form of subsets where sites with fewer species are subsets of areas with more species (Baselga 2010, Podani \& Schmera 2011, Legendre 2014). To estimate beta diversity and the type of process (nesting or turnover) that predominated in the sampled snake assemblages, we used the "beta.div" function (Legendre 2014) implemented in $\mathrm{R}$ to measure total beta diversity (BDtotal), estimated as Jaccard distance, between the sampled areas (BDtotal ranging from 0 to 0.5 , with 0.5 indicating high dissimilarity). To evaluate the relative importance of each site to the estimate of beta diversity we used the index of local contribution to total beta diversity (LCBD) suggested by Legendre \& De Cáceres (2013). This index represents the degree of singularity of a sample unit in relation to the composition of assemblages sampled. All these analyzes were performed in the R environment (R Core Team 2019) using the "adesspatial" package (Legendre \& Cáceres 2013).

The diversity profile was calculated from Hill's series using the equation $\mathrm{N} \alpha=[\log (\mathrm{p} 1 \alpha+\mathrm{p} 2 \alpha+\mathrm{p} 3 \alpha+\ldots+\mathrm{ps} \alpha)] /(1 \alpha)$, where $\mathrm{N} \alpha$ is an index of diversity given an $\alpha$ and ps, where ps is the proportion of individuals of a species $\mathrm{s}$ in a given locality. When the value of $\alpha=0$ the diversity index is equivalent to species richness, when $\alpha=1$ the diversity index is equivalent to the Shannon index and when $\alpha=2$ the diversity index is equivalent to the Simpson index. The use of Hill's series allows one to not only isolate the effects of using different indexes when estimating species diversity, but also to estimate how completely the local assembly was sampled (Melo 2008).

In order to analyze the structure of the snake assemblages in the six study areas, we generated graphs of relative abundance of species. Relative abundance is a component of biodiversity and refers to how common or rare a species is relative to other species in a determined area. It is the number of individuals of a given species relative to the total number of specimens of all species in the area (Magurran 2004). This method is used as an indicator of community structure and can be compared with theoretical models that try to describe, for example, how competition determines the structuring of a biological community (Margalef 1991, Magurran 2004).

To compare the efficacy of each sampling method (TCS, PIT, EO e OET) used in this study, we used the abundance and richness of snake species separated by sampling method. Abundance was standardized in terms of efficiency (abundance/effort) for each method (Rocha et al. 2004). For this comparison we used only the data referring to the TCS and PIT methods, since EO and OET methods had non-standard sampling efforts.

\section{Results}

Seventy snake species belonging to eight families were recorded: Aniliidae $(\mathrm{n}=1)$, Boidae $(\mathrm{n}=5)$, Colubridae $(\mathrm{n}=15)$, Dipsadidae $(\mathrm{n}=35)$, Elapidae $(\mathrm{n}=7)$, Leptotyphlopidae $(\mathrm{n}=1)$, Viperidae $(\mathrm{n}=5)$, and Typhlopidae $(\mathrm{n}=1)$. The highest number of species was recorded from the Trombetas River, where 28 snake species were collected ( $40 \%$ of the total species), followed by the Japurá and Tapajós Rivers with 25 species each (35.7\% each), Purus River with 21 species (30\%), Negro River with 19 species (27.1\%), and Jatapu River with 10 species (14.3\%) (Table 2, Figures 2-7).

There was pronounced variation in patterns of species composition (Figure $8 \mathrm{~A}$ ), as suggested by the high value (0.40) of BDtotal using the Jaccard distance. Replacement was responsible for most of the differences in beta diversity patterns among our sampled areas, with a value of $0.29(72.5 \%$ of 0.40$)$. Nestedness had a minor effect, with a value of $0.11(27.5 \%$ of 0.40$)$. We examined the interrelationships between these variables in a triangular plot (Figure 8B) that represents the replacement and nestedness values for all pairs of sampling areas (Podani \& Schmera 2011). The LCBD analysis showed that Jatapu River was the only area with a significant contribution for the overall beta diversity pattern $(\mathrm{p}=0.012)$.

The Hill's series (Figure 9) shows that the values of beta diversity could only be compared between the Trombetas and Tapajós, Japurá and Tapajós, Japurá and Jatapu, and between Purus, Negro and Jatapu rivers. The diversity among the combinations of remaining areas could not be compared since the generated curves intersect, revealing that those assemblages are not comparable to each other (Tóthmérész 1995). The highest diversity was found in the Trombetas River, and the lowest diversity was observed in the Jatapu River.

The distribution of relative abundances in each area shows that the most abundant species were Erythrolamprus reginae semilineatus, Helicops hagmanni, and Oxyrhopus vanidicus (Jatapu River), Bothrops atrox (Negro and Tapajós Rivers), Amerotyphlops reticulatus (Purus 
Table 2. Richness and abundance (N) of snakes sampled in the areas of the Jatapu River (Jat), Negro River (Neg), Purus River (Pur), Tapajós River (Tap), Trombetas River (Tro), and Japurá River (Jap), located in Brazilian Amazonia.

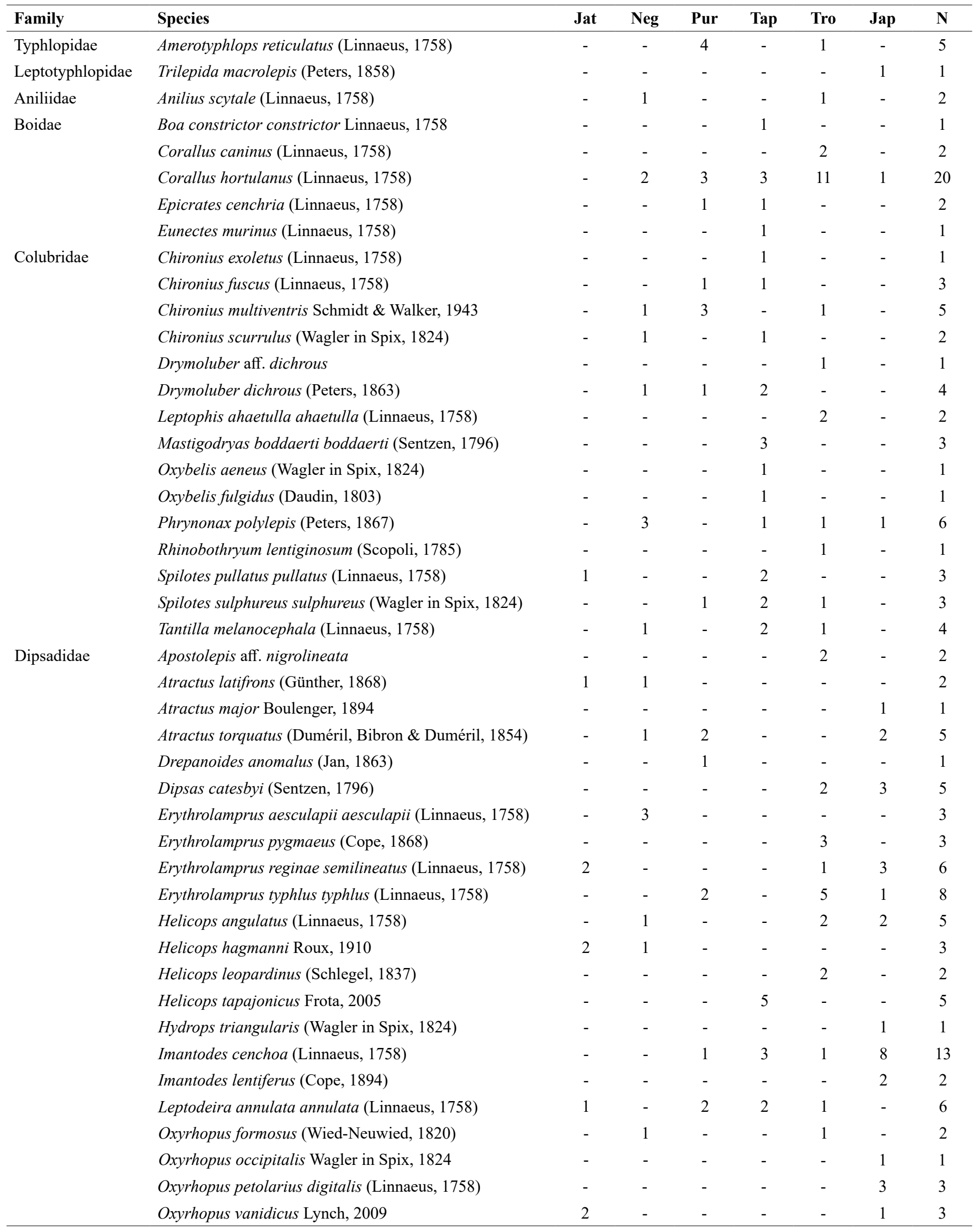


Continuation Table 2.

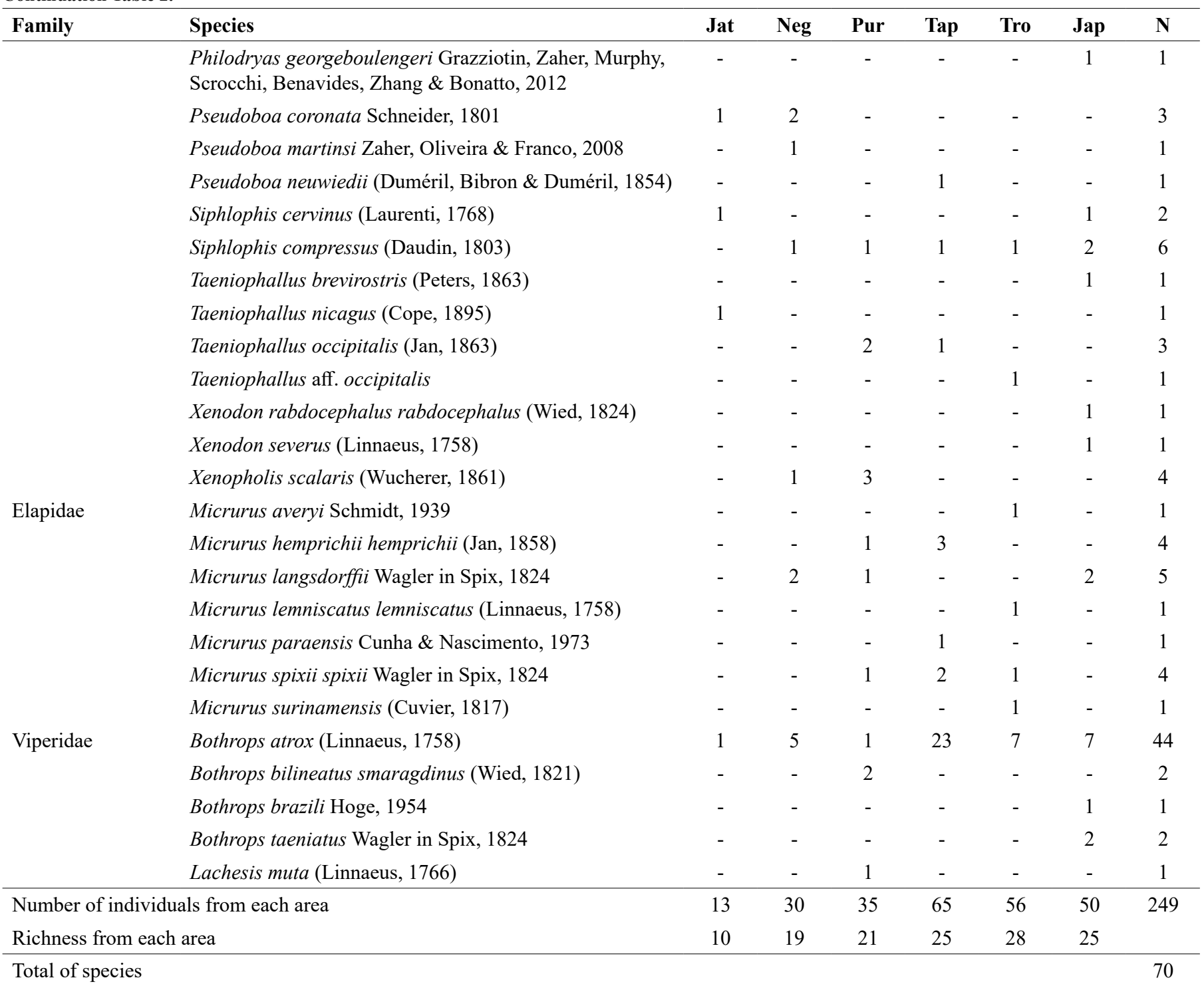

River), Corallus hortulanus (Trombetas River), and Imantodes cenchoa (Japurá River) (Figure 10).

TCS was the method that registered the largest number of individuals in the studied areas ( $\mathrm{n}=110,44.1 \%$ of the individuals sampled), with an efficacy of 0.27 individuals/hour. It was also the method that registered the largest number of species $(n=41)$. The use of PIT resulted in 28 records of individuals ( $11.2 \%$ of the total number of individuals), and an efficacy of 0.05 individuals/day, with 17 species being registered by this method of which seven species were registered only by PIT.

The OET and OE methods represented $22.4 \%$ and $22.0 \%$ of the collected individuals, respectively, with 27 species collected by OET and 29 species by OE (Table 3 ).

\section{Discussion}

The snake fauna recorded in this study corresponds to $37 \%$ of the species listed for the Brazilian Amazonia (Prudente 2017). The number of species collected per area was on average 21 , a quantity comparable to that found in other studies of Amazonian snakes employing similar methods and efforts (e.g. Turci \& Bernarde 2008, França et al. 2017). However, other studies of Amazonian snakes (e.g. Bernarde 2011, Waldez et al. 2013, Freitas et al. 2017, Morato et al. 2018) registered more species. This difference is likely due to the much greater sampling effort employed in these studies (ranging from a few months to years). Considering that our sampling was conducted for less than a month (20 days), it is very likely that the snake assemblages of each of the six studied areas contain additional still-to-be-recorded species.

The greatest species richness and diversity was detected from the Trombetas River, probably due to the number of species $(n=11)$ sampled exclusively in this area (Apostolepis aff. nigrolineata, Corallus caninus, Drymoluber aff. dichrous, Erythrolamprus pygmaeus, Helicops leopardinus, Leptophis ahaetulla ahaetulla, Rhinobothryum lentiginosum, Micrurus averyi, Micrurus lemniscatus lemniscatus, Micrurus surinamensis, and Taeniophallus aff. occipitalis). With the exception of the three unidentified species, the remaining eight species sampled only in Trombetas region are considered to be widely 

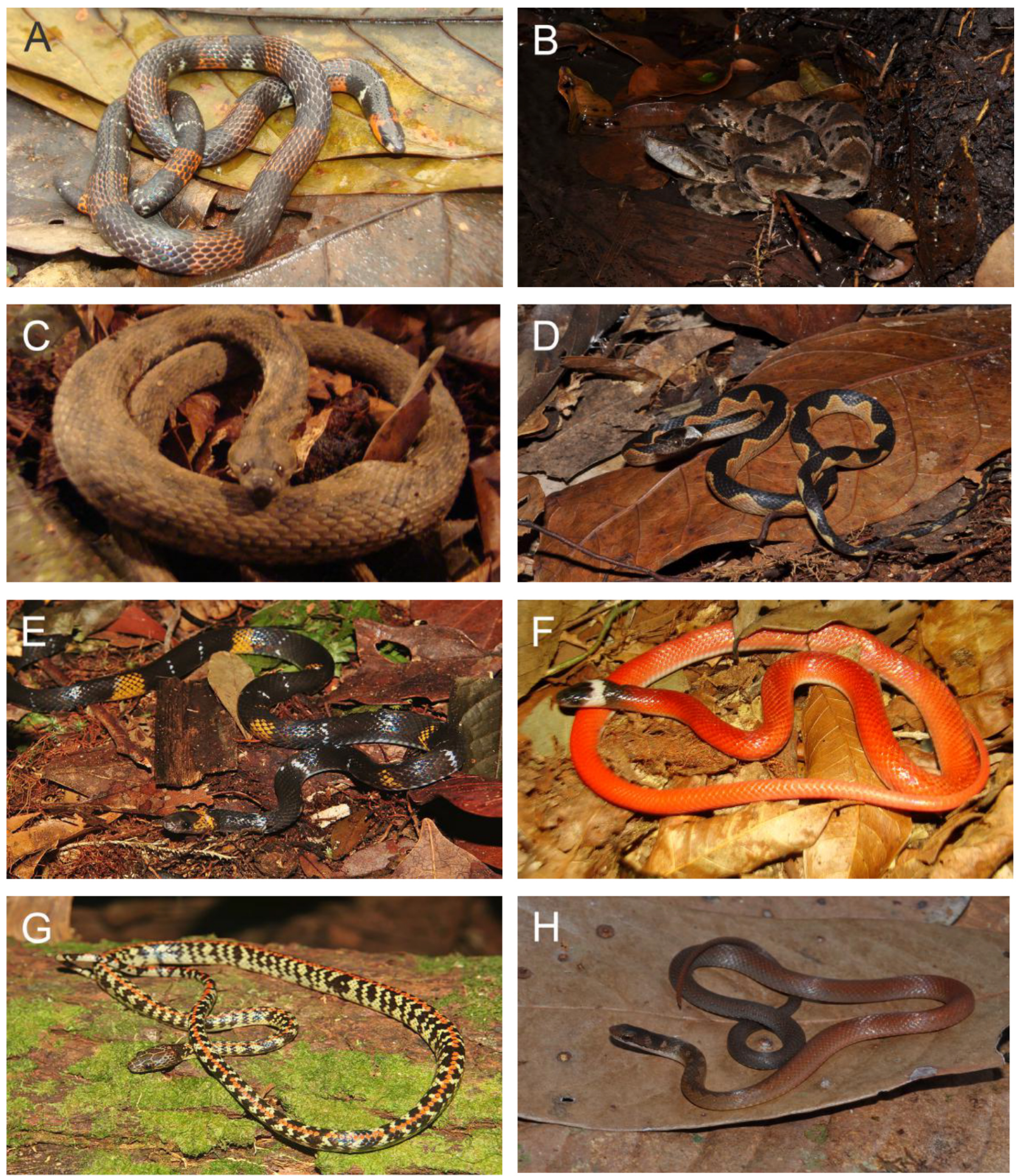

Figure 2. Snake species recorded in Jatapu River, Amazonas state, Brazil. A) Atractus latifrons; B) Bothrops atrox; C) Helicops hagmanni; D) Leptodeira annulata annulata; E) Oxyrhopus vanidicus; F) Pseudoboa coronata; G) Siphlophis cervinus, and H) Taeniophallus nicagus. 
Frazão, L. et al.
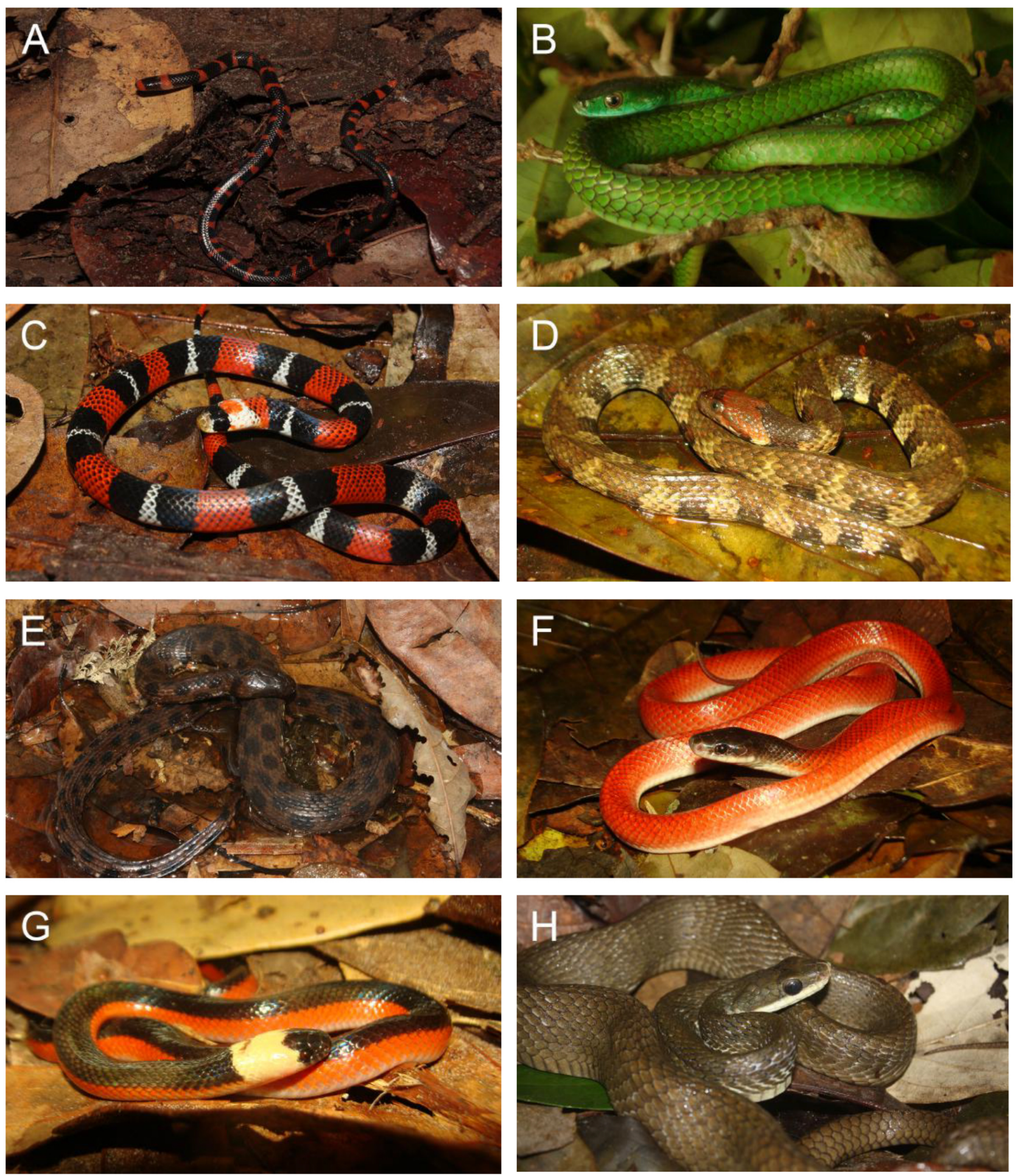

Figure 3. Snake species recorded in Negro River, Amazonas state, Brazil. A) Anilius scytale; B) Chironius scurrulus; C) Erythrolamprus aesculapii aesculapii; D) Helicops angulatus; E) Helicops hagmanni; F) Pseudoboa coronata; G) Pseudoboa martinsi, and H) Phrynonax polylepis. 

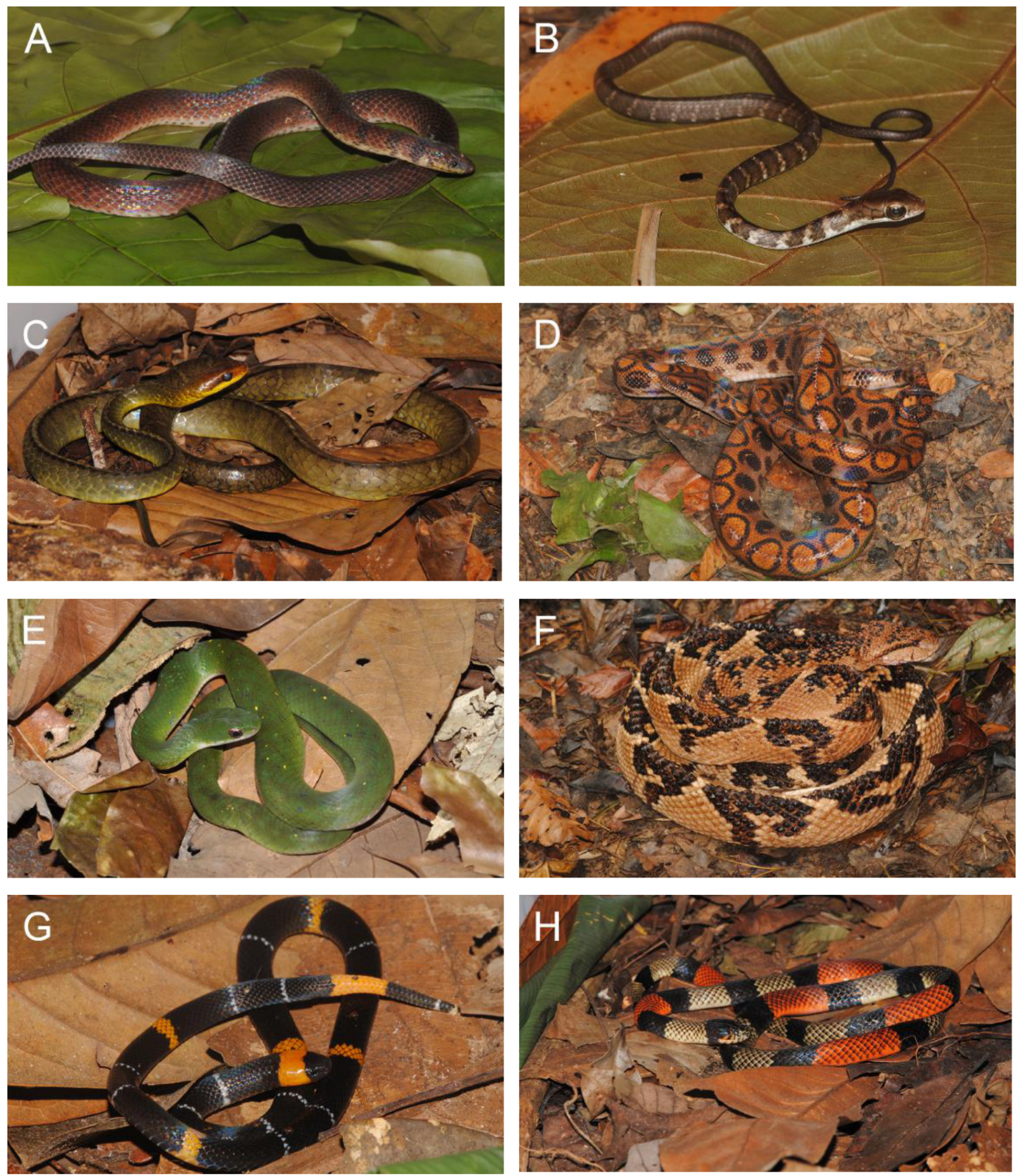

Figure 4. Snake species recorded in Purus River, Amazonas state, Brazil. A) Atractus torquatus; B) Chironius fuscus; C) Chironius multiventris; D) Epicrates cenchria; E) Erythrolamprus typhlus typhlus; F) Lachesis muta; G) Micrurus hemprichii hemprichii, and H) Micrurus spixii spixii. 

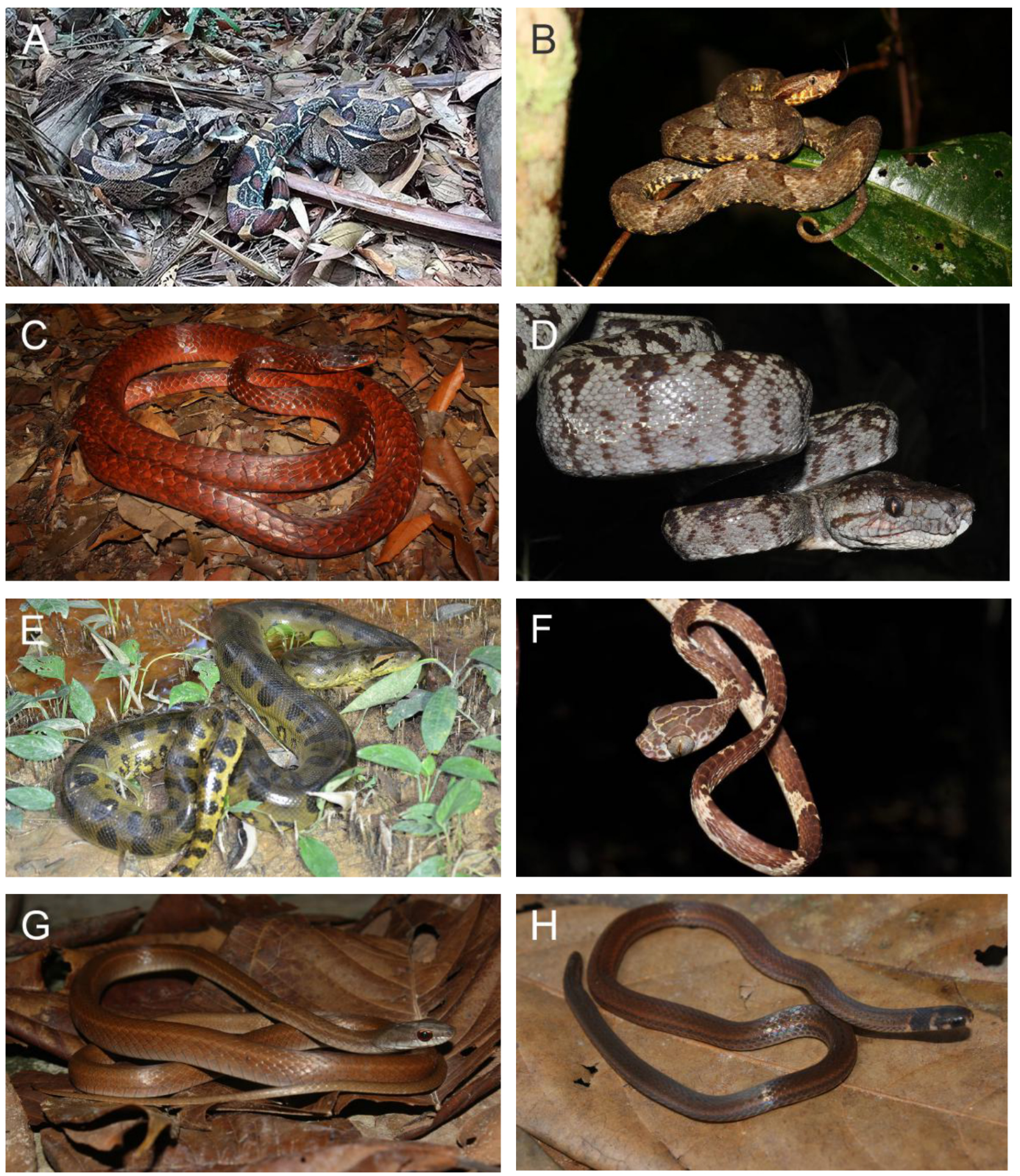

Figure 5. Snake species recorded in Tapajós River, Pará state, Brazil. A) Boa constrictor constrictor; B) Bothrops atrox; C) Chironius scurrulus; D) Corallus hortulanus; E) Eunectes murinus; F) Imantodes cenchoa; G) Mastigodryas boddaerti boddaerti, and H) Tantilla melanocephala. 

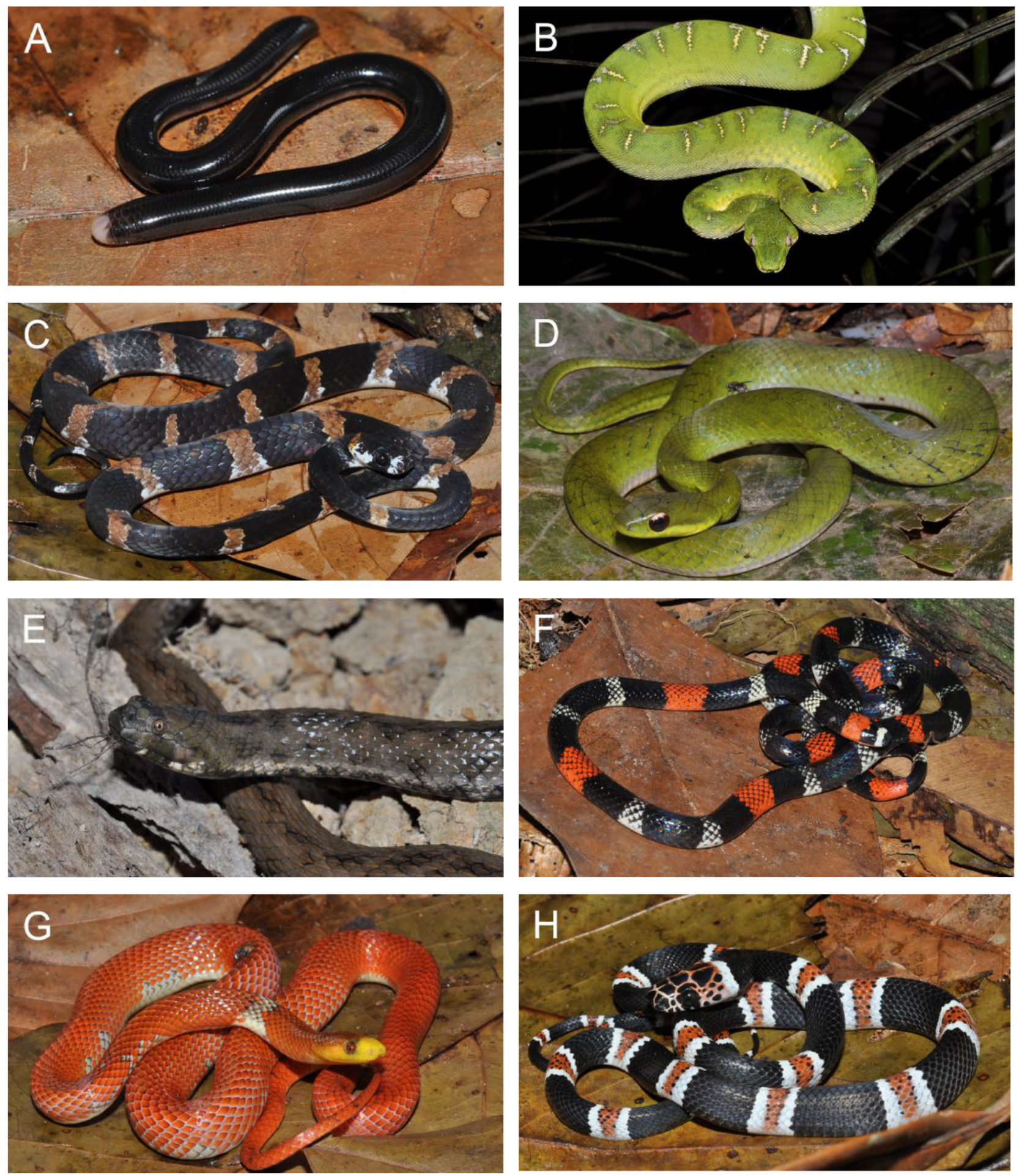

Figure 6. Snake species recorded in Trombetas River, Pará state, Brazil. A) Amerotyphlops reticulatus; B) Corallus caninus; C) Dipsas catesby; D) Erythrolamprus typhlus typhlus; E) Helicops leopardinus; F) Micrurus lemniscatus lemniscatus; G) Oxyrhopus occipitalis, and H) Rhinobothryum lentiginosum. 

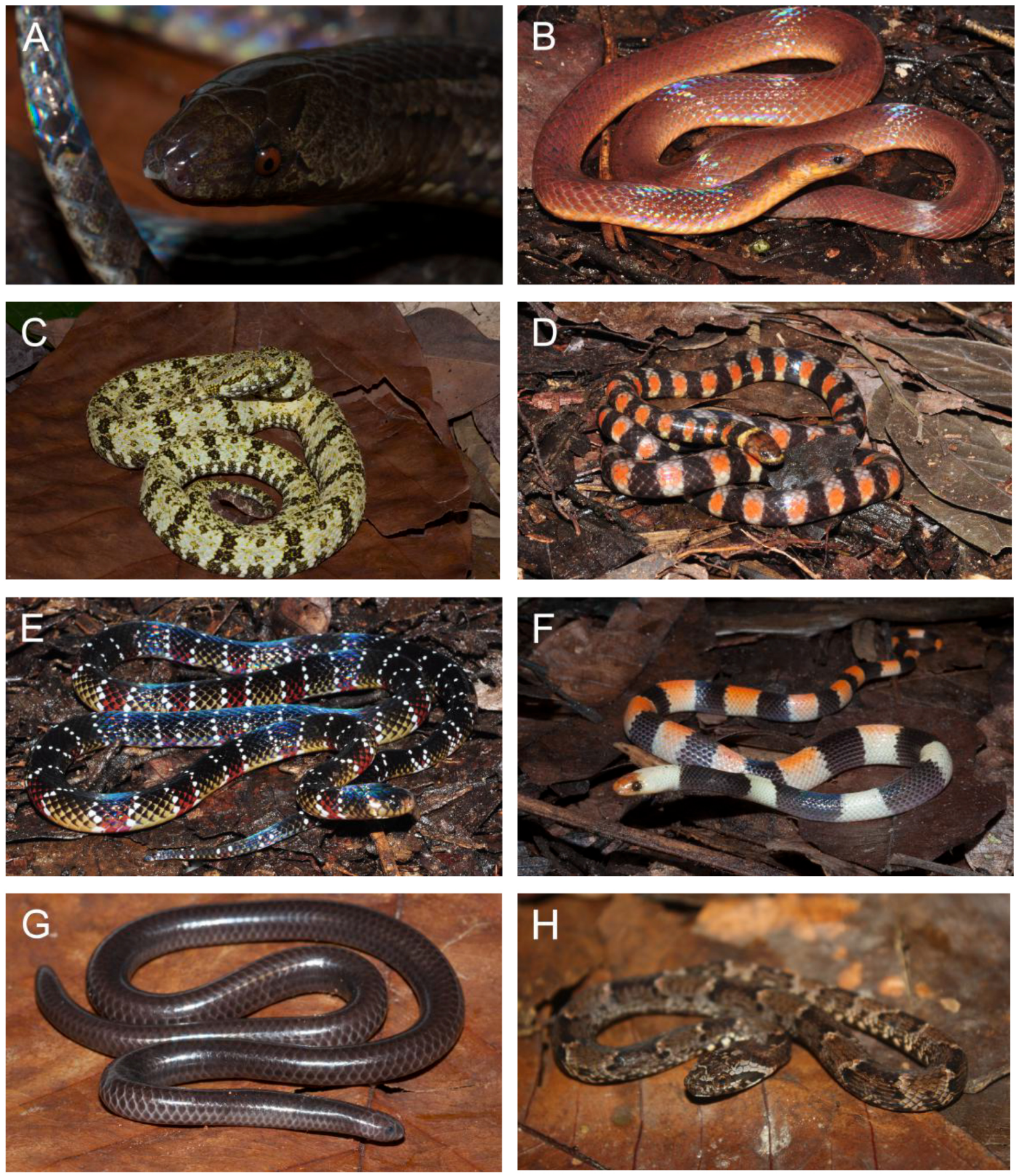

Figure 7. Snake species recorded in Japurá River, Amazonas state, Brazil. A) Atractus major; B) Atractus torquatus; C) Bothrops taeniatus; D) Hydrops triangularis; E) Micrurus langsdorffi; F) Oxyrhopus petolarius digitalis; G) Trilepida macrolepis, and H) Xenodon rabdocephalus rabdocephalus. 
A)
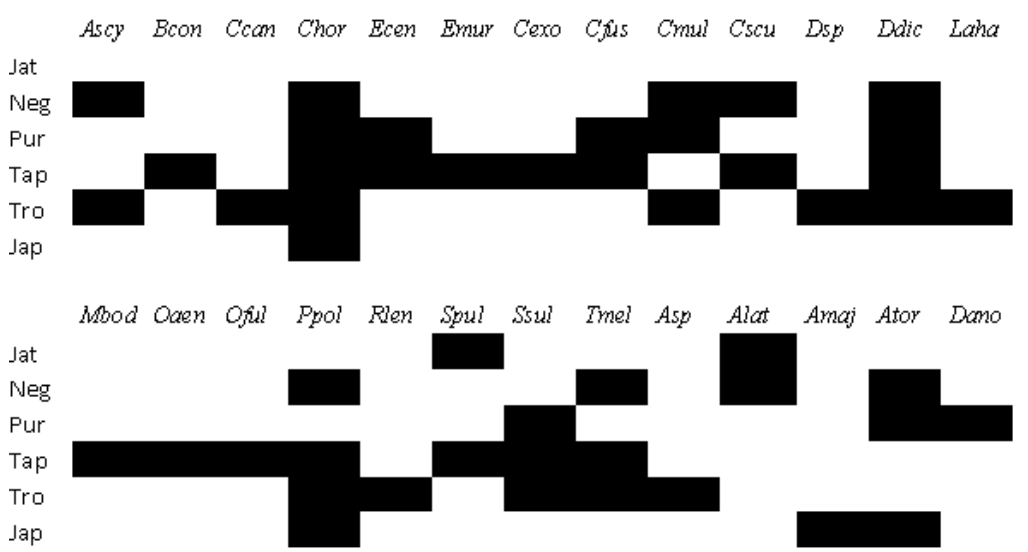

B)

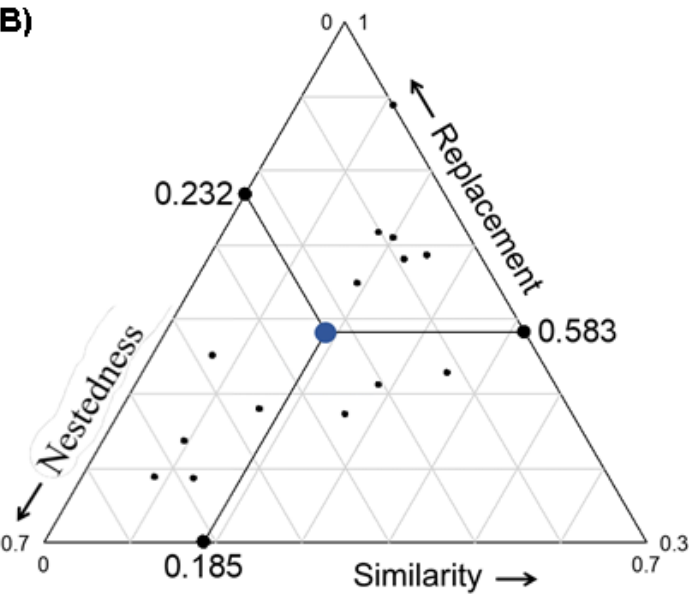

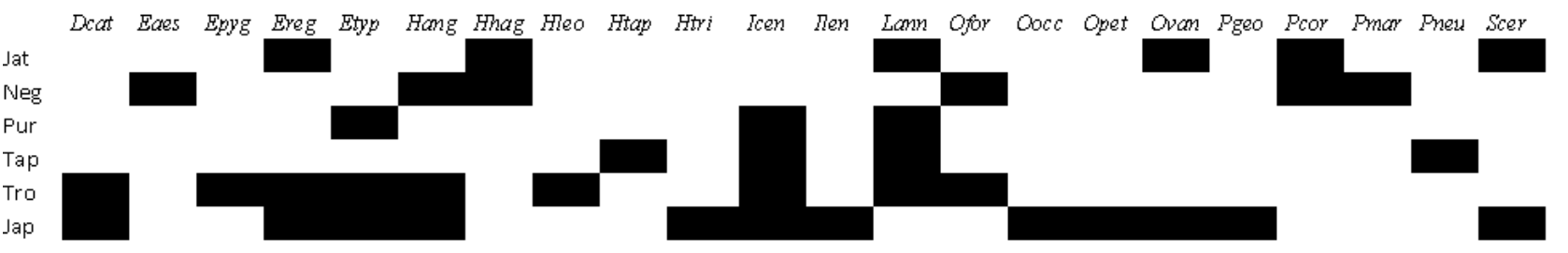

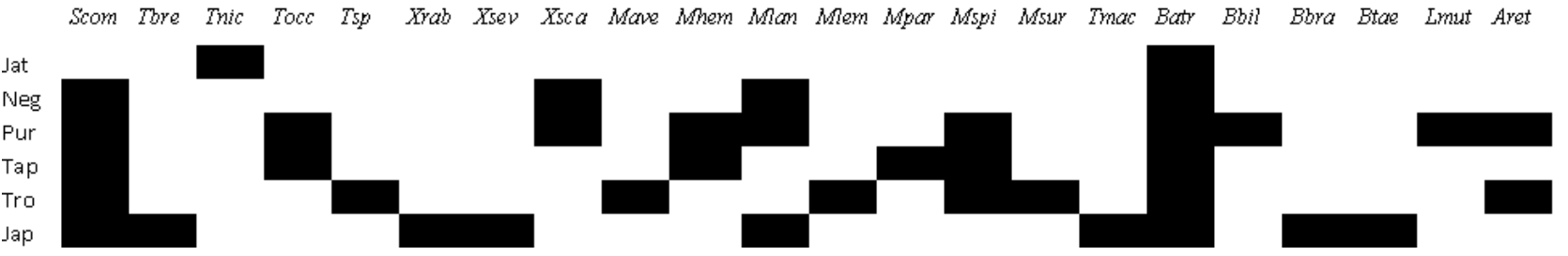

Figure 8. Graphic representation of beta diversity analysis. (A) Matrix of presence-absence of snake species sampled in each area. Species codes in the columns represent: Ascy: Anilus scytale, Bcon: Boa constrictor constrictor, Ccan: Corallus caninus, Chor: Corallus hortulanus, Ecen: Epicrates cenchria, Emur: Eunectes murinus, Cexo: Chironius exoletus, Cfus: Chironius fuscus, Cmul: Chironius multiventris, Cscu: Chironius scurrulus, Dsp: Drymoluber aff. dichrous, Ddic: Drymoluber dichrous, Laha: Leptophis ahaetulla ahaetulla, Mbod: Mastigodryas boddaerti boddaerti, Oaen: Oxybelis aeneus, Oful: Oxybelis fulgidus, Ppol: Phrynonax polylepis, Rlen: Rhinobothryum lentiginosum, Spul: Spilotes pullatus pullatus, Ssul: Spilotes sulphureus sulphureus, Tmel: Tantilla melanocephala, Asp: Apostolepis aff. nigrolineata, Alat: Atractus latifrons, Amaj: Atractus major, Ator: Atractus torquatus, Dano: Drepanoides anomalus, Dcat: Dipsas catesbyi, Eaes: Erythrolamprus aesculapii aesculapii, Epyg: Erythrolamprus pygmaeus, Ereg: Erythrolamprus reginae semilineatus, Etyp: Erythrolamprus typhlus typhlus, Hang: Helicops angulatus, Hhag: Helicops hagmanni, Hleo: Helicops leopardinus, Htap: Helicops tapajonicus, Htri: Hydrops triangularis, Icen: Imantodes cenchoa, Ilen: Imantodes lentiferus, Lann: Leptodeira annulata annulata, Ofor: Oxyrhopus formosus, Oocc: Oxyrhopus occipitalis, Opet: Oxyrhopus petolarius digitalis, Ovan: Oxyrhopus vanidicus, Pgeo: Philodryas georgeboulengeri, Pcor: Pseudoboa coronata, Pmar: Pseudoboa martinsi, Pneu: Pseudoboa neuwiedii, Scer: Siphlophis cervinus, Scom: Siphlophis compressus, Tbre: Taeniophallus brevirostris, Tnic: Taeniophallus nicagus, Tocc: Taeniophallus occipitalis, Tsp: Taeniophallus aff. occipitalis, Xrab: Xenodon rabdocephalus rabdocephalus, Xsev: Xenodon severus, Xsca: Xenopholis scalaris, Mave: Micrurus averyi, Mhem: Micrurus hemprichii hemprichii, Mlan: Micrurus langsdorffi, Mlem: Micrurus lemniscatus lemniscatus, Mpar: Micrurus paraensis, Mspi: Micrurus spixii spixii, Msur: Micrurus surinamensis, Tmac: Trilepida macrolepis, Batr: Bothrops atrox, Bbil: Bothrops bilineatus smaragdinus, Bbra: Bothrops brazili, Btae: Bothrops taeniatus, Lmut: Lachesis muta, Aret: Amerotyphlops reticulatus. (B) Triangular chart with breakdown of beta diversity components (nestedness and replacement) for each area sampled. This graph represents the turnover and nesting values, for all pairs of sampling areas. The larger blue point represents the centroid, and points interconnected by the centroid are mean values of similarity, turnover, and nestedness. 


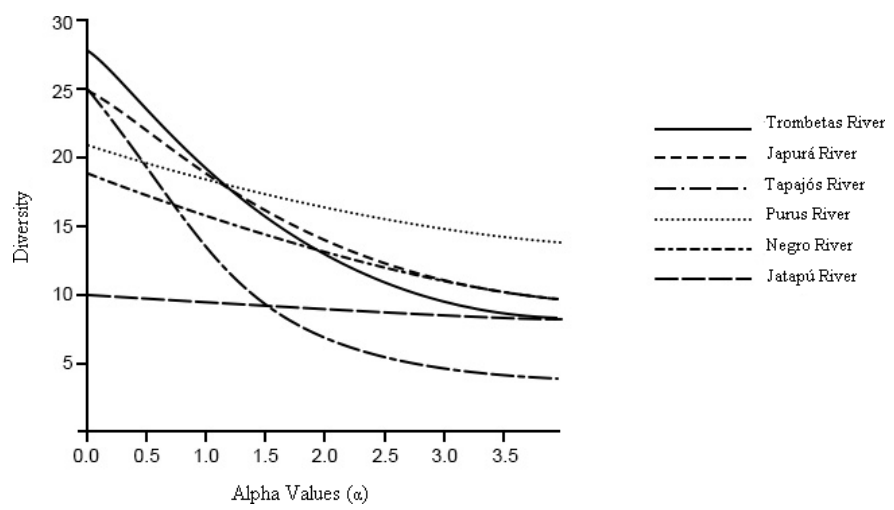

Figure 9. Diversity profiles of snake assemblages calculated for six sampled areas in the Brazilian Amazonia using the Hill's series. When $\alpha=0$, the index is equal to the species richness, when $\alpha=1$, we have a value almost identical to the Shannon index and when $\alpha=2$, we have the Simpson index.
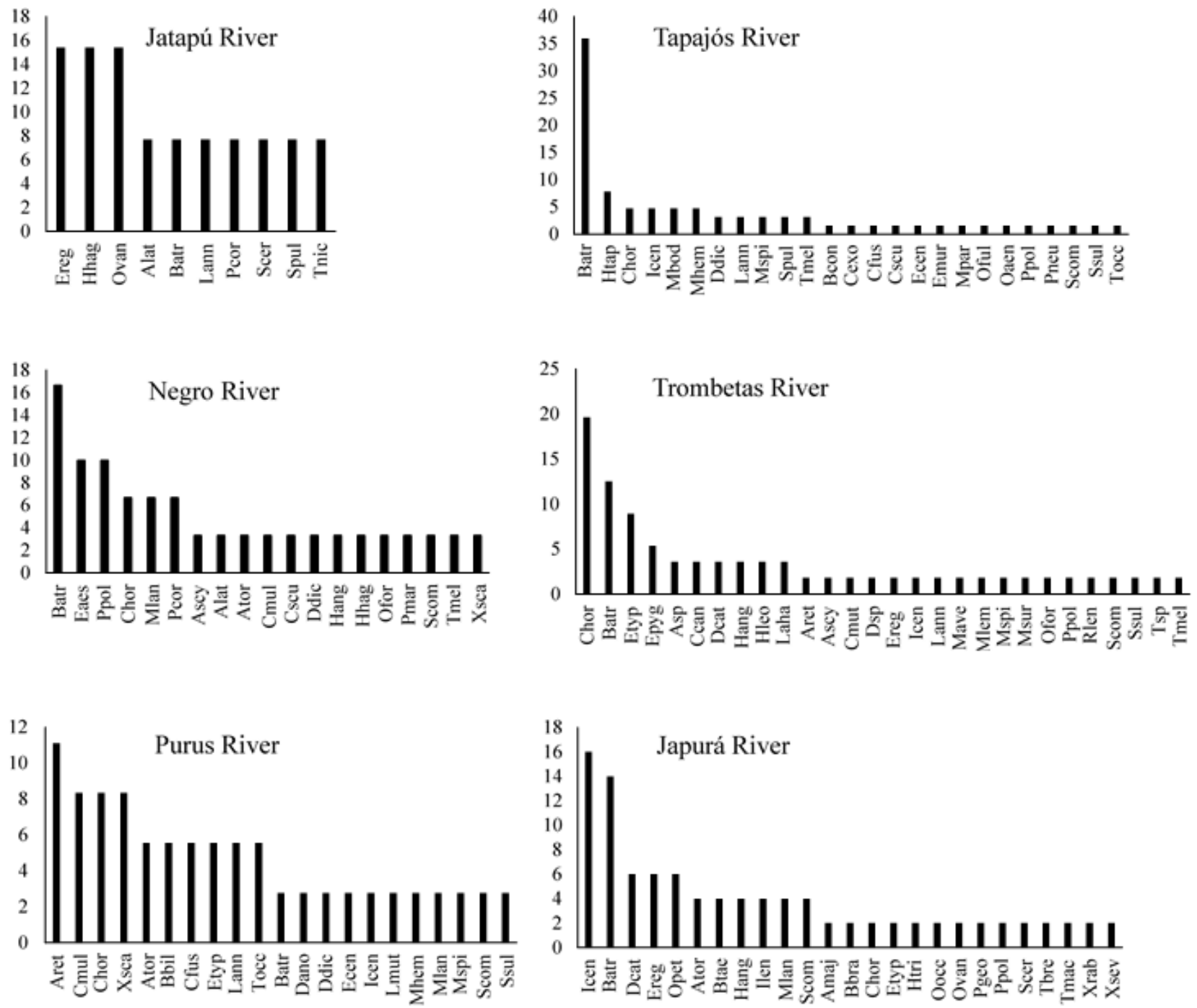

\section{Species}

Figure 10. Distribution of the relative abundances of snake species in each of the six sampled areas in the Brazilian Amazonia. See Figure 8 for acronyms. 
Amazonian snake communities

Table 3. Abundance of snake species sampled in six areas in the Brazilian Amazonia by the different sampling methods used. TCS: Time Constrained Search; PIT = Pitfall traps with drift fences; OET = Occasional Encounters by Third Parties and OE $=$ Occasional Encounters.

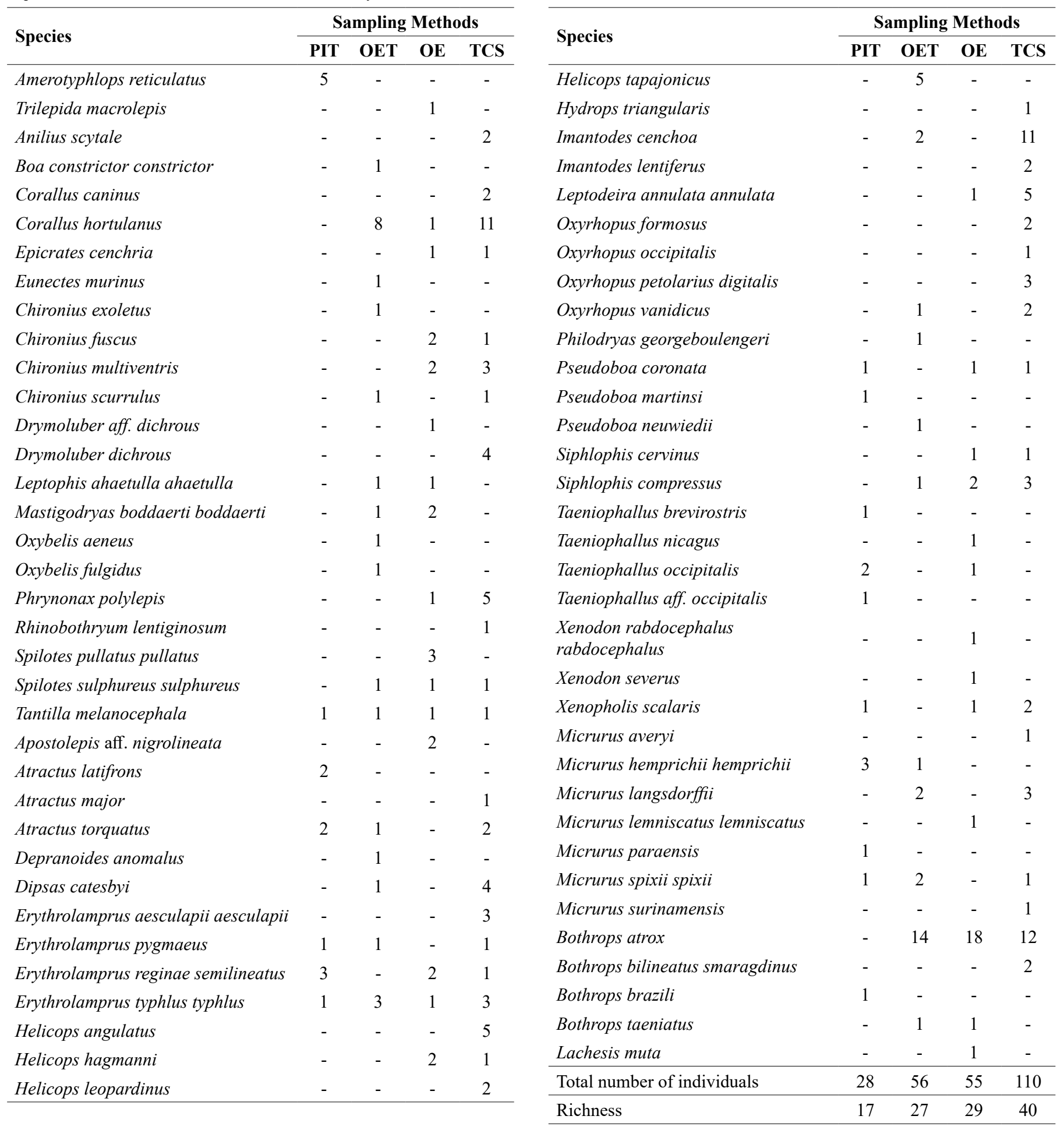


distributed in Amazonia (Costa \& Bérnils 2018, Uétz et al. 2018) and they probably have not been observed in other areas due to the low detectability of snakes, especially those from tropical forests (Kéry 2002, Steen 2010, Fraga et al. 2014). Low detectability of snakes causes false absences in tropical assemblages (Fraga et al. 2014), but we have to consider that some species, even with low detectability, are sampled more frequently than others (e.g. Bothrops atrox, Corallus hortulanus), probably due to their high abundances.

There is low sharing of species among the sampled areas since the snake assemblages in this study are structured mainly by replacement. It means that there is a strong heterogeneity in the Amazonian snake assemblages supported by the low species sharing and consequently high species substitution (turnover) indicated by beta diversity. However, it is important to consider that such high species turnover is partially related to differences in species richness and detectability among sampling localities. As an example, the Jatapu River area-the most depauperate area when considering number of species - showed a significant contribution for the overall beta diversity pattern. These results show the importance of spatially replicated snake surveys and corroborate Neckel-Oliveira \& Gordo (2004) and Bernarde et al. $(2012,2013)$ in showing that, although many snake species are widely distributed in the Amazonian biome, only a small proportion of the species occur-or are detected-in each locality. However, it is important to note that the high substitution of snake species in the sampled areas could be related to the broad spatial scale of our study (Soininen et al. 2015). This is because range of environmental variation increases with geographic scale (Heino et al. 2015), thus promoting species substitution.

The most abundant species $(n=44)$, which was responsible for dominance in two of the six localities, was the common lancehead (Bothrops atrox). This species is widely distributed throughout the Amazon Basin and has been reported as the most frequently sampled species in Amazonian snake surveys (Oliveira \& Martins 2001, Fraga et al. 2011, Masseli et al. 2019). Corallus hortulanus and Imantodes cenchoa were other species with high abundance in this study. Within the genus Corallus, C. hortulanus has the largest geographic distribution (pan South American), and is the most abundant species of the genus. This is probably due to the fact that it prays on a wide variety of animals, using diversity of hunting tactics (Henderson \& Pauers 2012). Imantodes cenchoa is distributed from the east coast of Mexico to Argentina. In Brazil, it occurs in the north, central-west, and northeast regions and is relatively abundant throughout Amazonia (e.g. Fraga et al. 2011). In our study, the highest abundance of this species was in the Japurá River, however, its elevated abundance in Japurá is an artefact of sampling, since on one night we collected a reproductive aggregation of one female and four males (Doan \& Arriaga 1999, Prudente \& Santos-Costa 2005). Many of the less abundant species of snakes registered in this study were singletons, with poorly known natural histories and distributions (e.g., Pseudoboa martinsi), or species with secretive habits and patchy geographic distributions (e.g., Micrurus avery, Micrurus l. lemniscatus) (Luiz et al. 2018, Prudente et al. 2018, Martins \& Oliveira 1999). These characteristics explain their low occurrence in faunistic surveys (e.g. Masseli et al. 2019).
The TCS was the method that most frequently registered individuals in the study areas (44.1\% of the total), sampling 40 species $(57.1 \%)$. The following species were recorded only by this method: Anilius scytale, Corallus caninus, Rhinobothryum lentiginosum, Atractus major, Erythrolamprus aesculapii aesculapii, Helicops angulatus, Helicops leopardinus, Hydrops triangularis, Imantodes lentifurus, Oxyrhopus occipitalis, Oxyrhopus petolarius digitalis, Micrurus averyi, and Micrurus surinamensis. Typically, TCS is the method that registers the greatest number of species (Avila-Pires et al., 2007) and this pattern is observed in surveys conducted in Amazonia (Duellman 1978, França \& Venâncio 2010, Prudente et al. 2010, Pantoja \& Fraga 2012, Waldez et al. 2013, Maynard et al. 2016). Arboreal and aquatic snake species are almost exclusively registered by this method (Avila-Pires et al. 2007, Prudente et al. 2010).

The pitfall traps captured 28 individuals (11.2\%) representing 17 species $(24.2 \%)$. The low rate of snake capture by this technique was expected. Greenberg et al. (1994) reported that PIT captured fewer species, but sampling with complementary techniques is highly recommended to obtain a better representation of the local fauna (Cechin \& Martin 2000, Ávila-Pires et al. 2007), since individual techniques do not sample all environments or even all organisms in an environment. PIT mainly captures semifossorial and highly camouflaged terrestrial species, as observed in the present study where the species Amerotyphlops reticulatus, Atractus latifrons, Bothrops brazili, Micrurus paraensis, Pseudoboa martinsi, Taeniophallus brevirostris, and Taeniophallus aff. occipitalis were recorded only by this method. Most of these species have secretive habits and high camouflage capacity which also makes them less detectable by visual search.

The OET and OE, although not used for comparisons because they are not standardized collecting methods, contributed 17 species sampled exclusively by these methods. The OET method was the only one that recorded Boa constrictor, Eunectes murinus, Chironius exoletus, Oxybelis aeneus, Oxybelis fulgidus, Drepanoides anomalus, Helicops tapajonicus, Philodryas georgeboulengeri, and Pseudoboa newiedii, while OE was the only method to record Spilotes pullatus pullatus, Apostolepis aff. nigrolineata, Taeniophallus nicagus, Xenodon rhabdocephalus rabdocephalus, Xenodon severus, Micrurus lemniscatus lemniscatus, Trilepida macrolepis, and Lachesis muta. These results corroborate other herpetofaunal studies, in which OE and OET constitute complementary methods to TCS and PIT registering species that are not easily recorded using these last two methods (Macedo et al. 2008, Turci \& Bernarde 2008).

In conclusion, Amazonia is highly diverse with 189 broadly distributed snake species known from the Brazilian portion of the biome, however, this number is likely an underestimate. In many taxonomic groups "widely distributed" taxa in reality are distinct lineages or species often structured by areas of endemism or ecoregions (e.g. Schultz et al. 2016). The existence of this greater-than-expected diversity of snakes is supported by the collection of at least 3 groups of individuals that could not be identified to the species level, i.e. were morphologically distinct from any known described species, and the high rate of species substitution of species in the local assemblages $(72.5 \%$ of beta diversity explained by species turnover). These observations and conclusions reinforce the conclusions of Fraga et al. (2014) and Guedes et al. (2018) 
that Amazonia has a high potential to contain still-to-be-discovered and undescribed species, and parallel observations in other Amazonian herps (e.g. Carminer et al. 2017, Muniz et al. 2018, Bittencourt et al. 2019). Our results further highlight the importance of standardized faunal surveys in poorly sampled areas in the Amazonian biome.

\section{Supplementary material}

The following online material is available for this article:

Appendix I - Voucher specimens collected at the study sites.

\section{Acknowledgments}

The authors thank Sebastião Batista, Ocírio Pereira (Juruna), Raimundo (Zika), Pedro and all the field assistants who contributed to this work; to the local residents of the communities where we went and who helped to open tracks and in the fieldwork; to all researchers who participated in this project, in particular the other members of the herpetofauna team, Marcelo Gordo, Vinicius Tadeu de Carvalho, Priscila Azarak, Rommel Roberto Rojas, Elciomar Araújo, Sérgio Marques and Deyla Oliveira. Izeni Pires Farias for the financial support through the project CNPq/SISBIOTA-BioPHAM 563348/2010. The snake species list presented here is based on specimens collected during the CNPq-funded program entitled Sisbiota/Rede - BioPHAM (Sistema Nacional de Pesquisa em Biodiversidade/Rede de Pesquisa para ampliar o conhecimento sobre a biodiversidade de vertebrados da Amazônia brasileira com aplicações para seu uso e conservação), and for that we also thank CNPq for the scholarship support of the authors L. Frazão and A. Almeida and for the productivity grants to the authors Tomas Hrbek, Igor L. Kaefer and Marcelo Menin.

\section{Author Contributions}

Luciana Frazão, Tomas Hrbek, Marcelo Menin and Ermelinda Oliveira contributed to data collection, in the concept and design of the study, data analysis and interpretation and in the manuscript preparation. Igor L. Kaefer contributed to data analysis and interpretation and in the manuscript preparation. Juliana Campos and Alexandre Almeida contributed to data collection and in the manuscript preparation.

\section{Conflicts of interest}

The authors declare that they have no conflict of interest related to the publication of this manuscript.

\section{Ethics}

All procedures involving animals were in accordance with the ethical standards of the institution or practice at which the study was conducted (CFBio No 148/2012).

\section{References}

ALVARES, C.A., STAPE, J.L., SENTElHAS, P.C., de MORAES, G., LEONARDO, J. \& SPAROVEK, G. 2013. Köppen's climate classification map for Brazil. Meteorol. Z. 22(6): 711-728.
ÁVILA-PIRES, T.C.S. 1995. Lizards of Brazilian Amazonia (Reptilia: Squamata). Zool. Verh. Leiden 299: 1-706.

ÁVILA-PIRES, T.C.S., HOOGMOED, M.S. \& VITT, L.J. 2007. Herpetofauna da Amazônia. In Herpetologia no Brasil II (L.B. Nascimento \& M.E. Oliveira, eds.). Sociedade Brasileira de Herpetologia, Belo Horizonte, p.13-43.

BASELGA, A. 2010. Partitioning the turnover and nestedness components of beta diversity. Global Ecol. Biogeogr., 19: 134-143.

BERNARDE, P.S., MOURA-LEITE, J.C. 1999. Geographic distribution: Hydrodynastes gygas (Surucucu-do-pantanal). Herpetol. Rev. 30: 54.

BERNARDE, P.S. \& ABE, A.S. 2006. A snake community at Espigão do Oeste, Rondônia, southwestern Amazon, Brazil. South. Am. J. Herpetol. 1: 102-113.

BERNARDE, P.S, ALBUQUERQUE, S., OLIVEIRA, T. \& TURCI, L.C.B. 2012. Serpentes do Estado de Rondônia, Brasil. Biota Neotrop. 12(3): 154-182.

BERNARDE, P.S, ALBUQUERQUE, S., MIRANDA, D.B. \& TURCI, L.C.B. 2013. Herpetofauna da floresta do baixo rio Moa em Cruzeiro do Sul, Acre - Brasil. Biota Neotrop. 13(1): 220-244.

BERNARDE, P.S., MACHADO, R.A. \& TURCI, L.C.B. 2011. Herpetofauna da área do igarapé Esperança na Reserva Extrativista Riozinho da Liberdade, Acre - Brasil. Biota Neotrop. 11(3): 117-144.

BERNARDE, P.S., TURCI, L.C.B., ABEGG, A.D. \& FRANCO, F.L. 2018. A remarkable new species of coralsnake of the Micrurus hemprichii species group from the Brazilian Amazon. Salamandra 54 (4):249-258.

BERNARDE, P.S., TURCI, L.C.B. \& MACHADO, R.A. 2017. Serpentes do Alto Juruá, Acre - Amazônia Brasileira. 1 ed. Edufac, Acre.

BITTENCOURT, P.S., CAMPOS, Z., MUNIZ, F.L., MARIONI, B., SOUZA, B.C., Da SILVEIRA, R., De THOISY, B., HRBEK, T. \& FARIAS, I.P. 2019. Evidence of cryptic lineages within a small South American crocodilian: the Schneider's dwarf caiman Paleosuchus trigonatus (Alligatoridae: Caimaninae). PeerJ 7: e6580.

BÖHM, M., COLLEN, B., BAILIE, J.E.M., BOWLES, P., CHANSON, J., COX, N., ... \& ZUG, G. 2013. The conservation status of the world's reptiles. Biol. Cons. 157: 372-385.

CAMINER, M.A., MILÁ, B., JANSEN, M., FOUQUET, A., VENEGAS, P.J., CHAVÉZ, G., LOUGHEED, S.C. \& RON, S.R. 2017. Correction: Systematics of the Dendropsophus leucophyllatus species complex (Anura: Hylidae): Cryptic diversity and the description of two new species. Plos One 12(4): e0176902.

CARRASCO, P.A., MATTONI, C.I., LEYNAUD, G.C., SCROCCHI, G.J. 2012. Morphology, phylogeny and taxonomy of South American bothropoid pitvipers (Serpentes, Viperidae). Zool. Scr. 41: 1-15.

CECHIN, S.Z. \& MARTINS, M. 2000. Eficiência de armadilhas de queda (pitfall traps) em amostragens de anfíbios e répteis no Brasil. Rev. Bras. Zool. 17: 729-740

COSTA, H.C. \& BÉRNILS, R.S. 2018. Répteis do Brasil e suas unidades federativas: Lista de espécies. Herpetologia Brasileira (8)1: 11-57.

COUTO, L.F., TERRIBILE, L.C., FELIZOLA, D.F. \& JOSÉ, A. 2007. Padrões espaciais e conservação da diversidade de serpentes do bioma cerrado. Acta Sci. Bio. Sci. 29 (1): 65-73.

CRACRAFT, J. 1985. Historical biogeography and patterns of differentiation within the South American avifauna: areas of endemism. Ornithol. Monogr. 36: 49-84.

CUNHA, O.R. \& NASCIMENTO, F.P. 1978. Ofídios da Amazônia X - As cobras da região leste do Pará. Publicações Avulsas do Museu Paraense Emílio Goeldi 31: 1-218.

CUNHA, O.R. \& NASCIMENTO, F.P. 1993. Ofídios da Amazônia. As cobras da região Leste do Pará. Bol. Mus. Para. Emílio Goeldi, Zool. 9: 1-191.

DOAN, T.M. \& ARRIAGA, W.A. 1999. Imantodes cenchoa. Aggregation. Herpetol. Rev. 30: 102

DUELLMAN, W.E. 1978. The biology of an equatorial herpetofauna in Amazonian Ecuador. Miscellaneous Publication. Museum of Natural History, University of Kansas 65: 1-352.

FERRÃO, M., FILHO, J.A.S.R. \& SILVA, M.O. 2012. Checklist of reptiles (Testudines, Squamata) from Alto Alegre dos Parecis, southwestern Amazonia, Brazil. Herpetol. Notes 5: 473-480. 
FONSECA, W.L., SILVA, J.D., ABEGG, A.D., ROSA, C.M. \& BERNARDE, P.S. 2019. Herpetofauna of Porto Walter and surrounding areas, Southwest Amazonia, Brazil. Herpetol. Notes 12: 91-107.

FRAGA, R., ALMEIDA, A.P., MORAES, L.J.C.L., GORDO, M., PIRANI, R., ZAMORA, R.R., CARVALHO, V.T., PASSOS, P. \& WERNECK, F. 2017. Narrow endemism or insufficient sampling? Geographical range extension and morphological variation of the poorly known Atractus riveroi Roze, 1961 (Serpentes: Dipsadidae). Herpet. Rev. 48: 281-284.

FRAGA, R., LIMA, A.P \& MAGNUSSON, W.E. 2011. Mesoscale spatial ecology of a tropical snake assemblage: the width of riparian corridors in central Amazonia. Herpetol. J. 21: 51-57.

FRAGA, R., LIMA, A.P., PRUDENTE, A.L.C. \& MAGNUSSON, W.E. 2013. Guia de cobras da região de Manaus, Amazônia central. Editora INPA, Manaus.

FRAGA, R., MAGNUSSON, W.E., ABRAHÃO, C.R., SANAIOTTI, T.\& LIMA, A.P. 2013. Habitat selection by Bothrops atrox (Serpentes: Viperidae) in central Amazonia, Brazil. Copeia 4: 684-690.

FRAGA, R., STOW, A.J., MAGNUSSON, W.E. \& LIMA, A.P. 2014. The costs of evaluating species densities and composition of snakes to assess development Impacts in Amazonia. Plos One 9(8): 1-9.

FRANÇA, F.G.R. \& VENÂNCIO, N.M. 2010. Reptiles and amphibians of a poorly known region in southwest Amazonia. Biotemas 23(3): 71-84.

FRANÇA, D.P.F., FREITAS, M.A., RAMALHO, W.P. \& BERNARDE, P.S. 2017. Diversidade local e influência da sazonalidade sobre taxocenoses de anfíbios e répteis na Reserva Extrativista Chico Mendes, Acre, Brasil. Iheringia, Zool. 107: e2017023.

FRANCO, F.L. \& FERREIRA, T.G. 2003. Descrição de uma nova espécie de Thamnodynastes Wagler, 1830 (Serpentes, Colubridae) do nordeste brasileiro, com comentários sobre o gênero. Phyllomedusa 1: 57-74.

FROTA, J.G., SANTOS-Jr, A.P., CHALKIDIS, H.M. \& GUEDES, A.G. 2005. As serpentes da região do baixo rio Amazonas, oeste do Estado do Pará, Brasil (Squamata). Biociências 13(2): 211-220.

GRAZZIOTIN, F.G., ZAHER, H., MURPHY, R.W., SCROCCHI, G., BEVAVIDES, M.A., ZHANG, Y. \& BONATTO, S.L. 2012. Molecular phylogeny of the New World Dipsadidae (Serpentes: Colubroidea): a reappraisal. Cladistics 28: 437-459.

GREEBERG, C.H., NEARY, D.G. \& HARRIS, L.D. 1994. A comparison of herpetofaunal sampling effectiveness of pitfall, single-ended, and doubleended funnel traps used with drift fences. J. Herpetol. 28: 319-324.

GUEDES, T.B., SAWAYA, R.J., ZIZKA, A., LAFFAN, S., FAURBY, S., PYRON, R.A., BÉRNILS, R.S., JANSEN, M., PASSOS, P., PRUDENTE, A.L.C., CISNEROS-HEREDIA, D.F., BRAZ, H.B., NOGUEIRA, C.C., ANTONELLI, A. \& MEIRI, S. 2018. Patterns, biases and prospects in the distribution and diversity of neotropical snakes. Global Ecol. Biogeogr. 27: $14-21$

HERDENSON, R.W. \& PAUERS, M.J. 2012. On the diets of the neotropical treeboas (Squamata: Boidae: Corallus). South Am. J. Herpetol. 7(2): 172180

HEINO, J., NOKELA, T., SOININEN, J., TOLKKINEN, M., VIRTANEN, L. \& VIRTANEN, R. 2015. Elements of metacommunity structure and community-environment relationships in stream organisms. Freshwater Biology 60: 973- 988.

HOOGMOED, M.S. \& PRUDENTE, A.L.C. 2003. A new species of Atractus (Reptilia: Ophidia: Colubridae: Dipsadinae) from the Amazon forest region in Brazil. Zool. Meded. 77: 425-439.

KÉRY, M. 2002. Inferring the absence of a species-a case study of snakes. J. Wildl. Manage. 66: 330-338.

LUIZ, L.F., CAMPOS, J., OLIVEIRA, M. E., CARVALHO, V. T. \& HRBEK, T. 2017. New record and revised distribution map of Pseudoboa martinsi Zaher at al., 2008 (Serpentes: Colubridae: Dipsadinae) in the state of Amazonas, Brazil. Herpetol. Notes 10: 193-195.

MAGNUSSON, W.E., LIMA, A.P., LUIZÃ, R., LUIZÃO, F., COSTA, F.R.C., CASTILHO, C.V. \& KINUPPI, V.F. 2005. RAPELD: uma modificação do método de Gentry para inventários de biodiversidade em sítios para pesquisa ecológica de longa duração. Biota Neotrop. 5(2): 1-6.
MAGURRAN, A.E. 2004. Measuring biological diversity. Blackwell Science Ltd, Oxford.

MARGALEF, R. 1991. Ecologia. Barcelona, Omega, XXVII+951p.

MARQUES, O. A. V. 1998. Composição faunística, história natural e ecologia de serpentes da Mata Atlântica, na região da Estação Ecológica Juréia-Itatins, São Paulo, SP. Tese de Doutorado, Universidade de São Paulo.

MARTINS, M. \& OLIVEIRA, M.E. 1998. Natural history of snakes in forests of the Manaus region, Central Amazonian, Brazil. Herpetol. Nat. Hist. 6: 78-150.

MASSELI, G.S., BRUCE, A.D., SANTOS, J.G., VINCENT, T. \& KAEFER, I.L. 2019. Composition and ecology of a snake assemblage in an upland forest from Central Amazonia. An. Acad. Bras. Cienc. 91: e20190080.

MAYNARD, R.J., AALL, N.C., SAENZ, D., HAMILTON, P.S. \& KWIATKOWSKI, M. A. 2016. Road-edge effects on herpetofauna in a lowland amazonian rainforest. Trop. Conserv. Sci. 9(1):264-290.

MEIRI, S. \& CHAPPLE, D.G. 2016. Biases in the current knowledge of threat status in lizards, and bridging the 'assessment gap'. Biol. Conserv. 204: 6-15.

MELO, A.S. 2008. O que ganhamos 'confundindo' riqueza de espécies e equabilidade em um índice de diversidade? Biota Neotrop. 8(3): 21-27.

MIRANDA, D., VENÂNCIO, N. \& De ALBURQUERQUE, S. 2014. Rapid survey of the herpetofauna in an area of forest management in eastern Acre, Brazil. Check List 10(4): 893-899.

MORATO, S.A.A., FERREIRA, G.N. \& SCUPINO, M.R.C. 2018. Herpetofauna da Amazônia central: Estudos na FLONA de Saracá-Taquera. STCP Engenharia de Projetos Ltda., Porto Trombetas: MRN - Mineração Rio do Norte S.A., Curitiba, p.1-210.

MUNIZ, F.L., CAMPOS, Z., HERNÁNDEZ-RANGEL, S.M., MARTÍNEZ, J.G., SOUZA, B.C., DE THOISY, B., BOTERO, R., HRBEK, T. \& FARIAS, I.P. 2018. Delimitation of evolutionary units in Cuvier's dwarf caiman, Paleosuchus palpebrosus (Cuvier, 1807): insights from conservation of a broadly distributed species. Conserv. Genet. 19: 599-610.

MYERS, C.W. \& McDOWELL, S.B. 2014. New Taxa and cryptic species of Neotropical snakes (Xenodontinae), with commentary on hemipenes as generic and specific characters. Bull. Am. Mus. Nat. Hist. 385: 1-112.

NECKEL-OLIVEIRA, S. \& GORDO, M. 2004. Anfíbios, lagartos e serpentes do Parque Nacional do Jaú. In Janelas para a biodiversidade no Parque Nacional do Jaú: Uma estratégia para o estudo na biodiversidade da Amazônia (S.H.Borges, S.H., S. Iwanaga, C.C. Durigan \& M.R. Pinheiro, eds.). Manaus, Fundação Vitória Amazônica. p. 161-173.

NELSON, B.W., FERREIRA, C.A.C., da SILVA, M.F., KAWASAKI, M. L. 1990. Endemism centres, refugia and botanical collection density in Brazilian Amazonia. Nature 345(6277): 714-716.

OLIVEIRA, M.E. \& MARTINS, M. 2001. When and where to find a pitviper: activity patterns and habitat us of the lancehead, Bothrops atrox, in central Amazonia, Brazil. Herpetol. Nat. Hist. 8(2): 101-110.

PANTOJA, D.L. \& De FRAGA, R. 2012. Herpetofauna of the Reserva Extrativista do Rio Gregório, Juruá Basin, southwest Amazonia, Brazil. Check List 8(3):360-374.

PASSOS, P., SCANFERLA, A., MELO-SAMPAIO, P.R., BRITO, J. \& ALMENDARIZ, A. 2019. A giant on the ground: another large-bodied Atractus (Serpentes: Dipsadinae) from Ecuadorian Andes, with comments on the dietary specializations of the goo-eaters snakes. An. Acad. Bras. de Ciênc. 9: e20170976.

PEET, R.K. 1974. The measurement of species diversity. Ann. Rev. Ecol. Evol. Syst. 5: 285-307.

PODANI, J. \& SCHMERA, D. 2011. A new conceptual and methodological framework for exploring and explaining pattern in presence-absence data. Oikos 120: 1625-1638.

PRUDENTE, A.L.C., MASCHIO, G.F., SANTOS-COSTA, M.C. \& FEITOSA, D.T. 2010. Serpentes da Bacia Petrolífera de Urucu, Município de Coari, Amazonas, Brasil. Acta Amazon. 40(2): 381-386.

PRUDENTE, A.L.C., SANTOS-COSTA \& M.C. 2005. Checklist of snakes from "Estação Científica Ferreira Penna", Eastern Amazonia, Pará State, Brasil. Bol. Mus. Para. Emílio Goeldi 1(2): 153:180. 
PRUDENTE, A.L.C. 2017. Censo da biodiversidade da Amazônia Brasileira MPEG: Serpentes. https://www.museu-goeldi.br/ (Last acess in 08/08/2018).

PRUDENTE, A.L.C., SARMENTO, J.F.M., AVILA-PIRES, T.C.S., MASCHIO, G. \& STURARO, M.J. 2018. How much do we know about the diversity of Squamata (Reptilia) in the most degraded region of Amazonia? South Am. J. Herpetol. 13(2): 117-130.

PRUDENTE, A.L.C., SILVA, F.M., MENKS, A. \& MELO, J. F. 2013. Checklist of Lizards of the Juruti, state of Pará, Brazil. Check List 9: 42-50.

R CORE TEAM. 2019. R: A language and environment for statistical computing. R Foundation for Statistical Computing, Vienna, Austria. https://www.Rproject.org/.

RIBAS, C.C., ALEIXO, A., NOGUEIRA, C.R., MIYAKI, C.Y. \& CRACRAFT, J. 2012. A paleobiogeographic model for biotic diversification within Amazonia over the past three million years. Proc. R. Soc. Edinb. Sect. B., Biol. Sci. 279: 681-689.

ROCHA, C.F.D., VAN SLUYS, M., HATANO, F.H., BOQUIMPANI-FREITAS, L., MARRA, R.V. \& MARQUES, R.V. 2004. Relative efficiency of anuran sampling methods in a restinga habitat (Jurubatiba, Rio de Janeiro, Brazil). Braz. J. Biol. 64(4): 879-884.

ROCHA, R.G., FERREIRA, E., SERAFINI, A., COSTA, L.P., NOGUEIRA, A.J.A., MALVASIO, A., RODRIGUES, M.T. 2005. Conservação dos répteis brasileiros: os desafios para um país megadiverso. Megadiversidade 1(1): 87-94.

RODRIGUES, G.M., MASCHIO, G.F. \& PRUDENTE, A.L.C. 2016. Snake assemblages of Marajó Island, Pará state, Brazil. Zoologia 33(1): e20150020.

SANTOS-COSTA, M.C., MASCHIO, G.F. \& PRUDENTE, A.L.C. 2015. Natural history of snakes from Floresta Nacional de Caxiuanã, eastern Amazonia, Brazil. Herpetol. Notes 8: 69-98.

SAWAYA, R.J., MARQUES, O.A.V. \& MARTINS, M. 2008. Composição e história natural das serpentes de Cerrado de Itirapina, São Paulo, sudeste do Brasil. Biota Neotrop. 8(2): 127-149.

SCHULTZ, E.D., BURNEY, C.W., BRUMFIELD, R.T., POLO, E.M., CRACRAFT, J. \& RIBAS, C.C. 2016. Systematics and biogeography of the Automolus infuscatus complex (Aves; Furnariidae): Cryptic diversity reveals western Amazonia as the origin of a transcontinental radiation. Mol. Phylogenet. Evol. 107: 503-515.

SILVA, F.M., MENKS, A.C., PRUDENTE, A.L.C., COSTA, J.C.L., TRAVASSOS, A.E.M. \& GALATTI, U. 2011. Squamata reptiles from municipality of Barcarena and surroundings, state of Pará, north of Brazil. Check List 7(3): 220-226.
SOININEN, J., BARTELS, P., HEINO, J., LUOTO, M., \& HILLEBRAND, H. 2015. Toward more integrated ecosystem research in aquatic and terrestrial environments. BioScience 65: 174- 182.

STEEN, D.A. 2010. Snakes in the grass: Secretive natural histories defy both conventional and progressive statistics. Herpetol. Conserv. Bio. 5: 183-188.

TÓTHMÉRÉSZ, B. 1995. Comparison of different methods for diversity ordering. J. Veg. Sci. 6(2): 283-290.

TURCI, L.C.B. \& BERNARDE, P.S. 2008. Levantamento herpetofaunístico em uma localidade no município de Cacoal, Rondônia, Brasil. Bioikos. 22: $101-108$

VAZ-SILVA, W., OLIVEIRA, R.M., GONZAGA, A.F.N., PINTO, K.C., POLI, F.C., BILCE, T.M., PENHACEK, M., WRONSLI, L., MARTINS, J.X., JUNQUEIRA, T.G., CESCA, L.C.C., GUIMARÃES, V.Y., PINHEIRO, R.D. 2015. Contributions to the knowledge of amphibians and reptiles from Volta Grande do Xingu, northern Brazil. Braz. J. Biol. 75(3): 205-218.

UETZ, P. 2018. The Reptile Database http://www.reptile-database.org/ (último acesso em 20/07/2018).

WALDEZ, F., MENIN, M. \& VOGT, R.C. 2013. Diversity of amphibians and Squamata reptilians from lower Purus River Basin, Central Amazonia, Brazil. Biota Neotrop. 13(1): 300-316.

WALLACH, V., WILLIAMS, K.L. \& BOUNDY, J. 2014. Snakes of the world. A catalogue of living and extinct species. New York, NY: CRC Press.

WHITTAKER, R.H. 1960. Vegetation of the Siskiyou Mountains, Oregon and California. Ecol. Monogr. 30: 280-338.

WILSEY, B.J., CHALCRAFT, D.R., BOWLES, C.M. \& WILLIG, M.R. 2005. Relationships among indices suggest that richness is an incomplete surrogate for grassland biodiversity. Ecology 86(5): 1178-1184.

VAZ-SILVA, W., 2009. Herpetofauna im zentral brasilianischen Cerrado. Terraria 17: 75-78.

ZAHER, H., GRAZZIOTIN, F.G., CADLE, J.E., MURPHY, R.W., MOURALEITE, J.C. \& BONATTO, S.L. 2009. Molecular phylogeny of advanced snakes (Serpentes, Caenophidia) with an emphasis on South American Xenodontines: a revised classification and descriptions of new taxa. Pap. Avulsos Zool. 49(11): 115-153. 